\title{
Risk assessment, disease prevention and personalised treatments in breast cancer: is clinically qualified integrative approach in the horizon?
}

Olga Golubnitschaja ${ }^{1,2^{*}}$, Kristina Yeghiazaryan ${ }^{1,2}$, Vincenzo Costigliola ${ }^{3}$, Daniela Trog ${ }^{1,2}$, Michael Braun ${ }^{2,4,5}$, Manuel Debald ${ }^{2,4}$, Walther Kuhn ${ }^{2,4}$ and Hans H Schild ${ }^{1,2}$

\begin{abstract}
Breast cancer is a multifactorial disease. A spectrum of internal and external factors contributes to the disease promotion such as a genetic predisposition, chronic inflammatory processes, exposure to toxic compounds, abundant stress factors, a shift-worker job, etc. The cumulative effects lead to high incidence of breast cancer in populations worldwide. Breast cancer in the USA is currently registered with the highest incidence rates amongst all cancer related patient cohorts. Currently applied diagnostic approaches are frequently unable to recognise early stages in tumour development that impairs individual outcomes. Early diagnosis has been demonstrated to be highly beneficial for significantly enhanced therapy efficacy and possibly full recovery. Actual paper shows that the elaboration of an integrative diagnostic approach combining several levels of examinations creates a robust platform for the reliable risk assessment, targeted preventive measures and more effective treatments tailored to the person in the overall task of breast cancer management. The levels of examinations are proposed, and innovative technological approaches are described in the paper. The absolute necessity to create individual patient profiles and extended medical records is justified for the utilising by routine medical services. Expert recommendations are provided to promote further developments in the field.
\end{abstract}

Keywords: Inflammation, Cancer, Metastasis, Biomarker pattern, Predictive diagnosis, Preventive healthcare, Medical services, Medical record, Integrative personalised medicine, Innovative technologies, Genetic testing, Assay, Omics, Imaging, Immune system, Metalloproteinase, Adjuvant therapy, Computer assistance, Mathematical modelling,

Tamoxifen, Ethics

\section{Review}

\section{Cancer context}

With the respect to the statistical data presented by the World Health Organisation [1], cancer is a leading cause of death worldwide, accounting for 7.6 million deaths (around 13\% of all deaths) as registered in 2008 and permanently increasing over 13 million as projected for 2030. Economic factors play a role, since about $70 \%$ of all cancer deaths in 2008 occurred in low- and middle-

\footnotetext{
* Correspondence: olga.golubnitschaja@ukb.uni-bonn.de

${ }^{1}$ Department of Radiology, Rheinische Friedrich-Wilhelms-University of Bonn, Sigmund-Freud-Str. 25, Bonn 53105, Germany

${ }^{2}$ Breast Cancer Research Centre, University of Bonn, Bonn, Germany

Full list of author information is available at the end of the article
}

income countries. The most fatal types of cancer are listed below in the decreasing order (deaths per year):

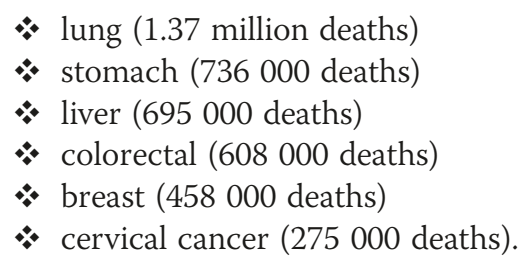

\section{Breast cancer is the most common cause of cancer-} related death among women

Hence in the USA, the highest cancer related incidence rates are currently registered for the breast cancer patient

\section{Ciomed Central}


cohorts [2] - see Figure 1A. The combating and treating measures such as induced population screening by mammography and application of adjuvant therapies, keep breast cancer mortality mostly unchanged or even persistently declined over last ten years - see Figure 1B. However, the incidence of breast cancer continually increases worldwide during the past three decades. According to the statistical data published by the National Cancer Institute in the USA [3], the estimated new cases and deaths from breast cancer in the United States in 2012 are (in thousand cases)

* New cases: 226.870 (female); 2.190 (male)

* Deaths: 39.510 (female); 410 (male)

Breast Cancer Metastatic Disease (BCMD) is currently incurable: challenges of diagnostics and treatment Breast Cancer Metastatic Disease (BCMD)

Diagnostic approaches routinely applied in medical practice are frequently unable to recognise early stages in breast cancer development that impair the outcome. At the time of diagnosis, a great portion of patients with breast cancer have locally advanced and/or distant metastatic disease. It is estimated that about $6 \%$ of breast cancer patients demonstrate a clinical picture of metastatic disease already at the time of diagnosis. Further $20 \%$ to $50 \%$ patients with primary breast cancer will develop metastatic disease despite the standardised treatments approached [4]. BCMD (stage IV) is the most advanced form of breast cancer. Once breast cancer has turned metastatic, the disease is recognised as the incurable one: the 5 -year survival barrier will be reached by only $26 \%$ of patients treated for the BCMD.

\section{Distant metastases}

The lion's share of about $90 \%$ of deaths in the overall breast cancer related mortality is caused by the distant metastases. Breast cancer spreads metastasis predominantly into lymph nodes, bone, lung, skin, brain, and liver [5], wherefrom only lymph nodes are considered as non-
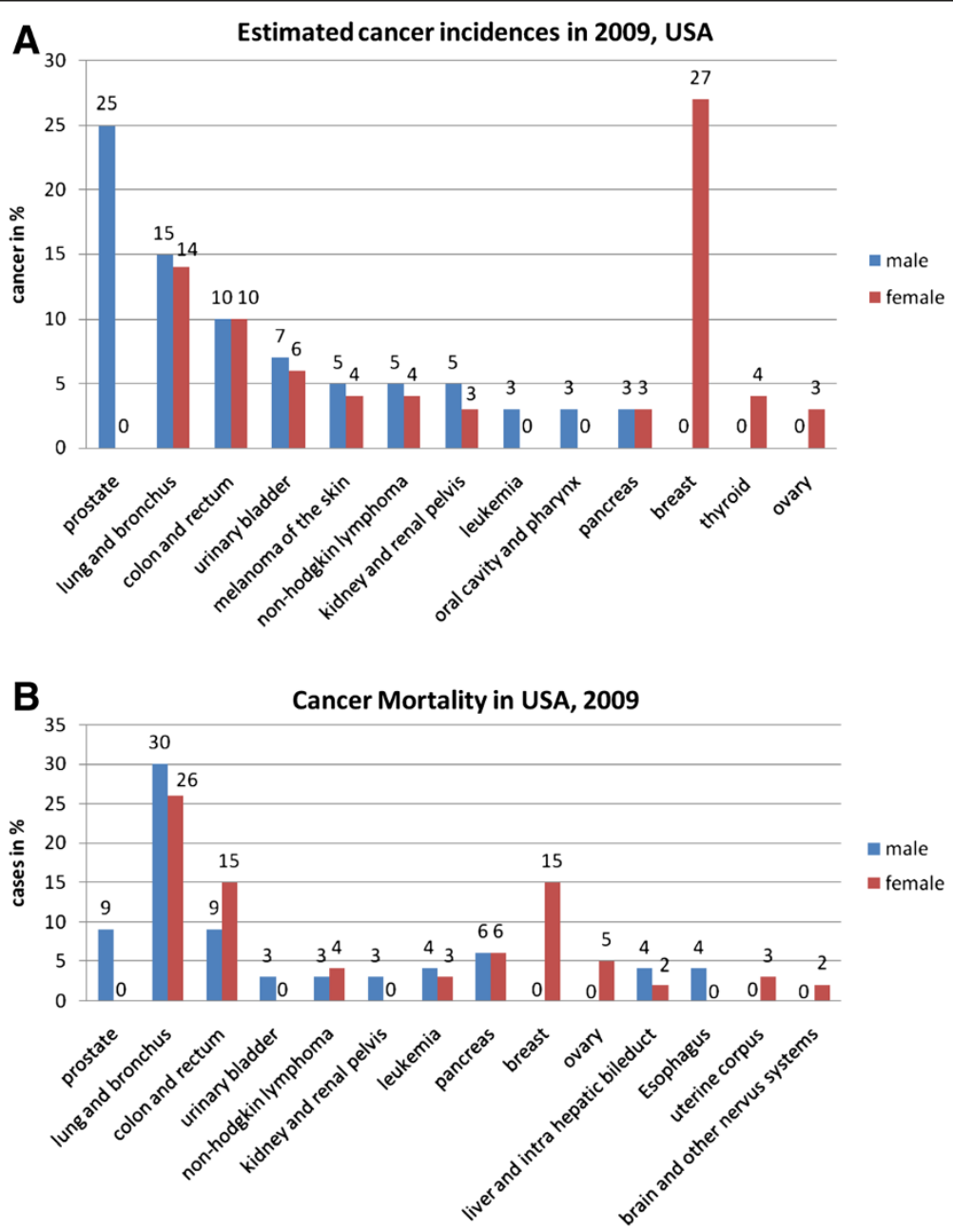

Figure 1 A. Estimated cancer incidence in USA in 2009; B. Cancer related mortality as registered in USA in 2009; data adapted from [2]. 
distance metastases. With the poorest prognosis of approximately $80 \%$ mortality rate within first 12 months of diagnosis, brain metastases represent a devastating category of BCMD. Brain metastases are prevalent in hormone receptor negative but HER2-overexpressing subgroups and are typical for $30 \%$ of all HER2+ BCMD [4]. The particular challenge in treating brain metastases is created by the limited permeability of the blood-brain barrier for chemotherapeutics, the use of which, further, leads to brain inflammatory response with extensive gliosis surrounding the metastases. The treated brain metastases are further provoked for high proliferation but minimal apoptosis demonstrating unsatisfactory effects of current treatments. Therefore, innovative diagnostic approaches to trace the micrometastases and therapeutic approaches aimed at stabilising and eliminating distant metastases - both do not exist yet being emergent in the nearest future.

\section{Diagnosis of BCMD}

Advanced imaging technologies are currently considered as being the most appropriate tool to diagnose BCMD, to detect the primary lesions and to trace the distance metastases over the whole body (whole-body imaging). To currently well recognised technologies belong multidimensional and multimodal ones: CT, MRI, PET, SPECT, and ultrasound; PET and the combined PET/CT is the key tool for the whole-body scanning. However, there are some substantial clinical deficits which imaging technologies suffer from in pinpointing the disease type [4].

RT-PCR Small-size metastases in lymph nodes may be detected by amplification of the smallest amounts of transcripts produced by BCMD biomarkers such as CK19 and others. The greatest limitation of the methodology is false-positive results potentially received due to the mixed cell populations which cannot be completely excluded by the resection. A conclusion might be also doubtful, due to untargeted biomarkers, particularly for heterogeneous tumours that is, indeed, the frequent case [4].

Disseminated and circulating tumour cells Individual tumour cells in bone marrow and blood stream cannot be detected by conventional imaging. For poor prognosis, more relevant and better detectable are tumour cells disseminated in bone marrow (DTC), compared to circulating tumour cells (CTC) in peripheral blood [6]. However, the invasiveness of the DTC sampling hardly finds the acceptance by patients. Consequently, blood tests for the CTC detection is a promising approach, in particular for the diagnosing of BCMD which demonstrates the most abundant representation of tumour cells in blood followed by high rates of CTC in prostate cancer, in contrast to significantly lower levels of CTC spread by other tumour types [7]. However, this approach suffers from substantial technological limitations such as an extremely low frequency of CTC in a blood stream that makes the tool almost useless for the detection of BCMD at its early stages [8]. Consequently, the reliable results' interpretation is currently possible only for the advanced stages of the tumour progression / BCMD and for patients with poor prognosis [9]. The promising diagnostic approach might be the molecular characterisation of CTC as the predictor of the tumour invasiveness and therapy response [6].

\section{Treatment of BCMD}

Currently applied strategies for the treatment of BCMD make use of systemic cytotoxic agents that lead to severe and irreversible organic side-effects significantly decreasing the life quality of the patients followed by a limited long-term success in metastasis suppression: only 1-3\% of patients remain long-term disease-free after BCMD treatments [4]. Although new agents like paclitaxel, trastuzumab and aromatase inhibitors improve the short-term survival rates (up to 36 months), the therapeutic goals remain at the level of survival prolongation and symptoms palliation.

The experts are fully consent with the fact that novel drug targets should be elaborated for a successful BCMD treatment tailored to the patient. In this context, molecular defects driving clinical onset of BCMD, beginning with the initiation step to the micrometastasis progression till BCMD virulence, create the robust panel of the drug target candidates [10]. Recent reports from animal models of BCMD treatments keep a hope in potential improvements which, however, are not going to happen for the patients tomorrow.

\section{Breast cancer risk assessment "Molecular portrait" and more}

Early detection of the tumour has been demonstrated to be highly beneficial for significantly enhanced therapy efficacy. An accurate navigation by predictive diagnosis may lead to full recovery after surgical resection [11]. Furthermore, a detection of individual predisposition to breast cancer represents the optimal way how the pathology may be diagnosed before its clinical onset and development of the fatal BCMD. Breast cancer risk assessment is currently extensively under consideration. The major problem, however, is linked to the multifactorial nature of the disease. Consequently, the list of parameters with impacts for the disease onset and progression at the individual level, i.e. personal risk factors differ significantly from patient to patient. This consideration leads to better understanding, why the "across-the -board" treatment of breast cancer is frequently ineffective, and the pathology specific "portrait" should be 
created at the individual level. On this, any biological manifestation is operated and controlled at the molecular level. Therefore, the "portrait featuring" originates from the specific set-up of individual biomolecules and corresponding interaction among relevant pathways at molecular, subcellular and cellular levels. This "molecular portrait" creates an individual condition for the disease predisposition and promotion, which is recognisable and modifiable through individual pathology specific "molecular patterns". For the clinically relevant and issue sensitive interpretation, the informational input from the "molecular patterns" should be combined with complementary technologies such as medical imaging, which altogether contribute to the creation of the individual "patient profiles" as the robust platform for personalised healthcare services. The expected outcomes are conducive to more effective population screening, prevention early in childhood, identification of persons at-risk, stratification of patients for the optimal therapy planning, prediction and reduction of adverse drug-drug or drug-disease interactions.

\section{Innate immune system as a putative origin of mammary gland}

Resulting from the accumulated data from knowledge about morphological particularities, cell composition bioinformatics research, a new concept to the evolutionary origin of mammary gland has been presented suggesting that the gland's initial function was the provision of innate immunity later evolving into its current nutritional role [12]. Indeed, immune cells are abundant in both physiologic and pathologic mammary tissue. The immune cells are implicated in the development of human mammary glands: leucocytic infiltrates have been detected in normal pubertal and adult gland tissue $[12,13]$. Furthermore, bone marrow depletion leads to blocked ductal elongation in murine experimental models of mammary gland development. Taking together the above listed facts, the decisive role of the immune cells in physiology of mammary glands is getting obvious. This fascinating discovery opens great perspectives for innovative diagnostic tools based on a minimally invasive blood test platform and might be highly beneficial for novel drug targets of increased efficacy in breast cancer treatments.

\section{Immune cells and inflammation as tumour modifiers in breast: expression patterns of activated leucocytes collaborative with neoplastic cells under chronic inflammatory condition?}

The paradoxical role of leucocytes as protectors, regulators, modifiers and causal players in the breast carcinogenesis becomes extensively discussed in current literatures. Both innate (myeloid) and adaptive (lymphoid) leucocyte types have been demonstrated as breast cancer modifiers [14]. Doubtless cytotoxic T-lymphocytes have a function in constraining tumour developments that is evident, in particular, for the tumours of viral origin [15]. On the other side, the chronic activation of leucocytes paradoxically play a role in initiating / potentiating carcinogenesis: infiltrating B-lymphocytes have been reported to represent the predominant lymphocytic population in premalignant breast tissue [14]. Further, B-cells represent the predominant lymphocytes during early breast cancer, whereas infiltrating T-lymphocytes are more extensive in higher graded ductal in situ and invasive breast carcinomas $[16,17]$.

What is the mechanism of the tumour promotion by inflammatory leucocytes? The key-point is their unique plasticity in producing protein products and bioactive mediators essential for all stages in the tumour progression such as reactive oxygen species, tissue-remodelling (e.g. metalloproteinases) angiogenesis prompting (e.g. VEGF) protein-complexes $[18,19]$. Certainly, this enormous capacity is conditioned by the stage specific expression patterns in activated leucocytes. Under the chronic inflammatory condition the expression patterns of infiltrating leucocytes obviously become collaborative with those of neoplastic cells. An excellent example is provided by tissue-remodelling proteins secreted from activated leucocytes. An altered metalloproteinase activity impacts directly the mammary gland physiology during morphogenesis, hormonal cycle and lactation, as well as during inflammatory acute / chronic process, cancer pre-lesions, tumour progression, and metastatic disease. Besides other cell types in the population, inflammatory and immune cells are the major producers of metalloproteinases [20]. Although the impacts of the metalloproteinase activities are well acknowledged for mammary glands physiology and pathophysiology, the relevance of the metalloproteinase patterns as the breast cancer modifiers in the context of inflammation and immune cells represents won its recognition only recently in the scientific world [21].

\section{Molecular patterns in activated leucocytes as the minimally invasive diagnostic tool for breast cancer risk assessment}

Pursuing the above conclusions, it is getting obvious that the molecular/expressional patterns in orchestrated leucocytes are activated strictly in accordance to the precancerous / cancer stage. If detected in correlation with the corresponding disease initiation and progression stage, these patterns in activated leucocytes might be of high relevance for the diagnostic and treatment purposes. This consideration leads to the idea of creating a minimally invasive approach for breast cancer risk assessment based on ex vivo blood tests by examination of 
the specific molecular/expressional patterns in circulating leucocytes.

The OVERALL TASK: Multimodal diagnostic approaches, disease specific biomarker-patterns, individual patient profiles, creation of medical records and treatments tailored to the person

Paradigm change from a delayed approach after clinical onset of the pathology to predictive diagnostics followed by targeted prevention and individualised treatment algorithms tailored to the patient, creates an innovative concept for advanced healthcare that is costs effective [22]. Particularly attractive are non-invasive diagnostic approaches considering disease-specific alterations in molecular patterns of blood cells and serum in predisposed individuals before clinically disease onset [11,23-29]. Identification of pathology-specific biomarker-patterns increases the specificity and predictive power of analytical approach. Combination of patterns at subcellular, intracellular and extracellular levels contributes to high sensitivity and specificity of the analysis. Mathematic modelling of patient-specific profiles allows for an accurate prediction of individual predisposition before the pathology is manifested. Integrative medical approach by predictive diagnostics, targeted prevention and personalised treatments is considered as the medicine of the future. The expected outcomes are conducive to more effective population screening, prevention early in life, identification of persons at-risk, stratification of patients for the optimal therapy planning, prediction and reduction of adverse drug-drug or drug-disease interactions relying on emerging technologies, such as medical imaging, pharmacogenetics, "omics, disease modelling, individual patient profiles, integrative medical records, etc.

\section{Technological design: integrative concept}

The integrative concept of the technological design is summarised in Figure 2. An optimal sep-up of stakeholders and a high quality of the performance of single operating steps (sub-projects) guarantee for a discovery and qualification of innovative diagnostic approaches and valid drug targets to be successfully implemented in clinical practice. The crucial step in the overall experimental scheme is a well-established patient model that reflects the clinical condition(s). Large-scaled studies to identify novel diagnostic biomarkers and therapeutic targets followed by validation, standardisation and application procedures are essential in breast cancer research.

\section{Creation of medical records}

Creation of medical records is the crucial step in the overall task of prediction, precise disease diagnosing and successful application of the treatment algorithms tailored to the person. Medical record should carry an integrative character presenting and evaluating disease relevant data at any applicable level of the examination / detection. The major points to be obligatory involved in the medical records related to the breast cancer are summarised below:

- Sur/name

- Date of birth / Age

- Ethnicity [30]

- Menopausal status [30]

- Menstrual cycle (duration, regularity etc.)

- History of pregnancies and childbirth

- Last date, type and result of past individual cancer screening (mammography, pap smear etc.)

- Breast / Cancer familial background (as described elsewhere)

- Histological statement for malignant tumours / benign indication

- Drug history: alcohol, nicotine etc.

- Medication history (i.e. steroids, blood pressure medication, anti-inflammatory medication etc.)

- For malignant tumours: evaluation of combined results by medical imaging, categorisation of the carcinoma (invasive lobular, ductal carcinoma in situ, etc.), TNM staging (size of cancer, nodal status,

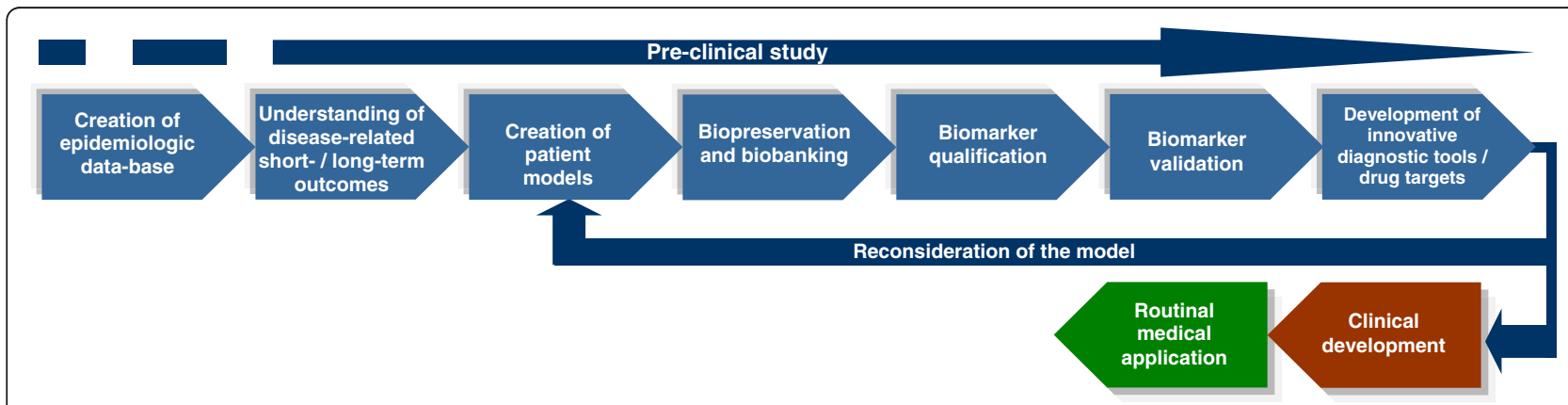

Figure 2 Moving from basic research to clinical implementation: basic steps in creating the robust diagnostic platform and treatments tailored to the person. 
type of metastases, receptor status, HER2, etc.) molecular subtypes (luminal a \& b, basal, etc.)

- For benign patients: acknowledged breast cancer risk factors (childless, lack of breast feeding, breast trauma / inflammations / biopsy, etc.) [30]

- Frequent co-morbidities (Diabetes type 2, cardiovascular disease, depression) $[31,32]$

- Environmental particularities (geographic factors, environmental toxicity, such as an excess of heavy metals and toxic compounds as described elsewhere)

- Inactive life-style and overweight (body mass index) that influence the pathology development and outcomes [31,32]

- Sleep disorders as the predisposition and the cause of cancer [33]

- Detectable stress factors with acknowledged impacts for BC development such as a shift-worker's job [34]

- Breast / Cancer specific molecular patterns in blood (as discussed later in text)

- Metastasis specific biomarkers in blood (medical imaging and CTC detection as discussed above)

\section{Construction of diagnostic windows for minimally invasive breast cancer risk assessment based on immune cells profiling}

This multimodal approach utilises a combination of conventional analytical methodology for a creation of the pathology specific biomarker patterns at complementary levels of detection, namely

- Medical imaging (primary tumour, distanced metastasis)

- Subcellular / molecular imaging by "comet assay" DNA analysis (risk assessment for general tumour predisposition)

- Clinical differential proteomics as the "gene hunting" approach for pathology specific molecular patterns in blood cells

- Blood metabolomics for quantification of disease relevant metabolite patterns

- Quantitative analysis of enzymatic activities in blood plasma

- others

followed by mathematical modelling of pathologyspecific profiles.

Here we demonstrate the analytical procedure for two levels of detection, namely molecular imaging by quantitative "comet assay" and clinical proteomics.

\section{Subcellular / molecular imaging by "comet assay"- analysis}

The "comet assay" provides a simple and effective method for evaluation of DNA damage and DNA-repair capacity in single cells such as leucocytes. The principle of the assay is based upon the ability of DNA fragments to migrate out of the cell under the influence of an electric field. An evaluation of the "comet" tail shape and DNA fragments migration pattern allows for assessment of DNA damage and repair capacity. DNA-damage is assigned to 4 classes based on the visual aspect of the comets, considering the extent of DNA migration as published earlier [35]. Comets with a bright head and almost no tail are classified as class I with minimal DNA damage. Comets with no visible head and a long diffuse tail are classified as class IV (severely damaged/apoptotic cells). Comets with intermediate characteristics are assigned to classes II and III dependent on the ratio $\mathrm{R}=\mathrm{T} / \mathrm{r}$, where $\mathrm{T}$ is a length of comet' $\mathrm{s}$ tail and $\mathrm{r}$ is a radius of comet' $\mathrm{s}$ head. The characteristic value of $R$ for class 1 is $1(T \approx r)$ and for class 4 is $\infty(r=0)$. Comets with values $1<R<3$ are classified as class 2 (see the original image). Comet classes are demonstrated with the image provided in the Figure 3.

Subcellular / molecular imaging by quantitative "comet assay" has characterised the breast cancer patients as follows:

$>$ Increased damage to DNA

$>$ Debilitated apoptotic reaction towards increased DNA damage

$>$ Pathology specific comet patterns

$>$ Impact of hormonal status on specificity of comet patterns among breast cancer patients

$>$ Characteristic windows of comet patterns that may be utilised for breast cancer risk assessment - both positive (at high-risk) and negative (at low-risk) prediction.

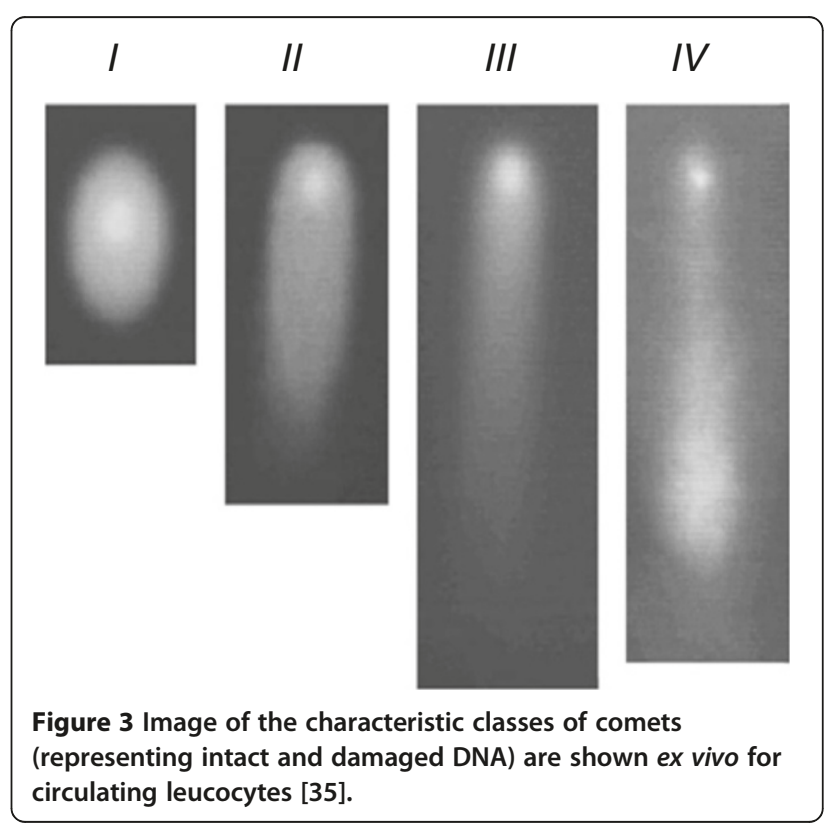


An example of the diagnostic windows for breast cancer risk assessment using comet classes I (intact DNA) and IV (apoptotic) is demonstrated in Figure 4 [36]. The constructed diagnostic windows clearly distinguish between tumour and benign patients and may be considered for the practical application in differential molecular diagnostics. For this diagnostic tool two parameters in medical records are of particular importance, namely the age and menopausal status.

Clinical differential proteomics as the promissing tool for breast cancer risk assessment

Protein mapping in circulating leucocytes of breast cancer patients

The protein mapping performed in our recent project resulted in altogether 158 protein spots distinguished; the overall spots correspond to 74 proteins the amino acid sequences of which have been consequently identified utilising the analytical technology of MALDI-TOF see Figure 5 [11]. The identified proteins are listed in the Table 1.
Concomitantly to the protein identification, the functional classification has been performed. The list of functional groups is provided with the separate Table 2.

\section{Breast cancer specific expression patterns as potential candidates for the predictive-diagnostic biomarker panel}

The expression profiles under the cancer condition have been quantified versus the control group with benign and no breast tumours detected [11]. The resulting information is provided in Table 1 . In accordance to statistical analysis, altogether four categories have been builtup as follows: A. statistically significant alterations in the expression profiles under the cancer condition compared to the control group; B. statistically non-significant alterations in the expression profiles under the cancer condition compared to the control group; C. expression levels altered individually with highly heterogeneous expression profiles within the patient group versus stable expression levels within the control group; D similar expression-profiles within both patient and control groups of comparison. Here detected pathology specific patterns might be further considered for the creation of

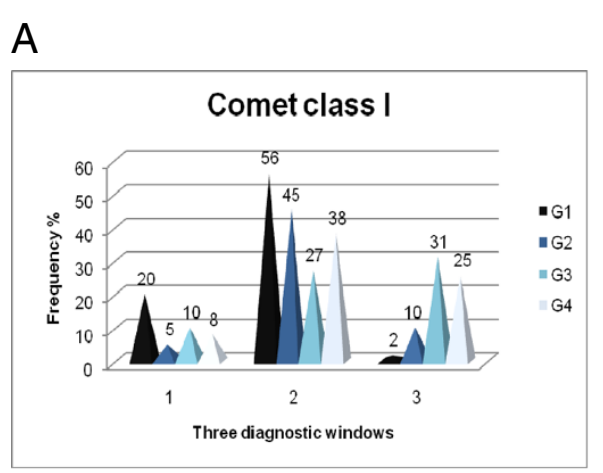

C

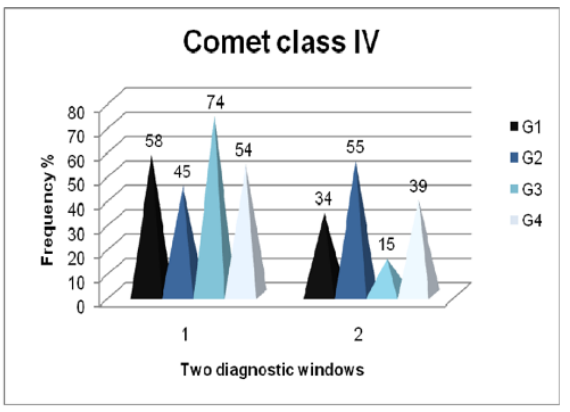

B

D
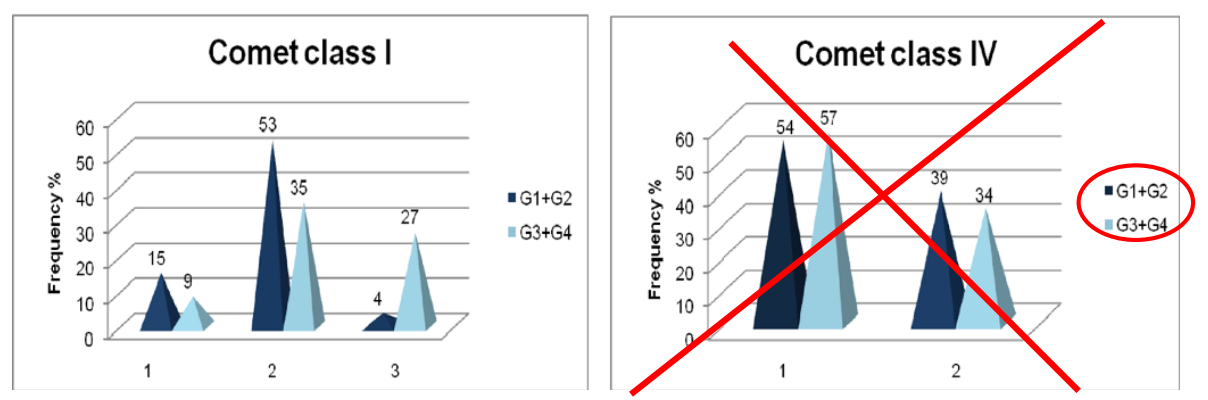

Figure 4 Diagrams estimating a predictive power of the comet-fractions (comet class I and IV), further utilised in the construction of diagnostic windows for breast cancer risk assessment (A, B and C); according to the diagnosis, the recruited patients are grouped as follows: pre-menopausal women with benign alterations in breast tissue (G1); post-menopausal women with benign alterations in breast tissue (G2); invasive lobular \& ductal carcinomas in pre-menopausal women (G3); invasive lobular \& ductal carcinomas in postmenopausal women (G4); data taken from [36]. Obviously, the diagnostic windows with the comet class IV patterns can be effective only when the hormonal status is considered as one of the selection parameters for subgrouping the patients and concomitant utilisation of the analytical approach proposed by this study. 


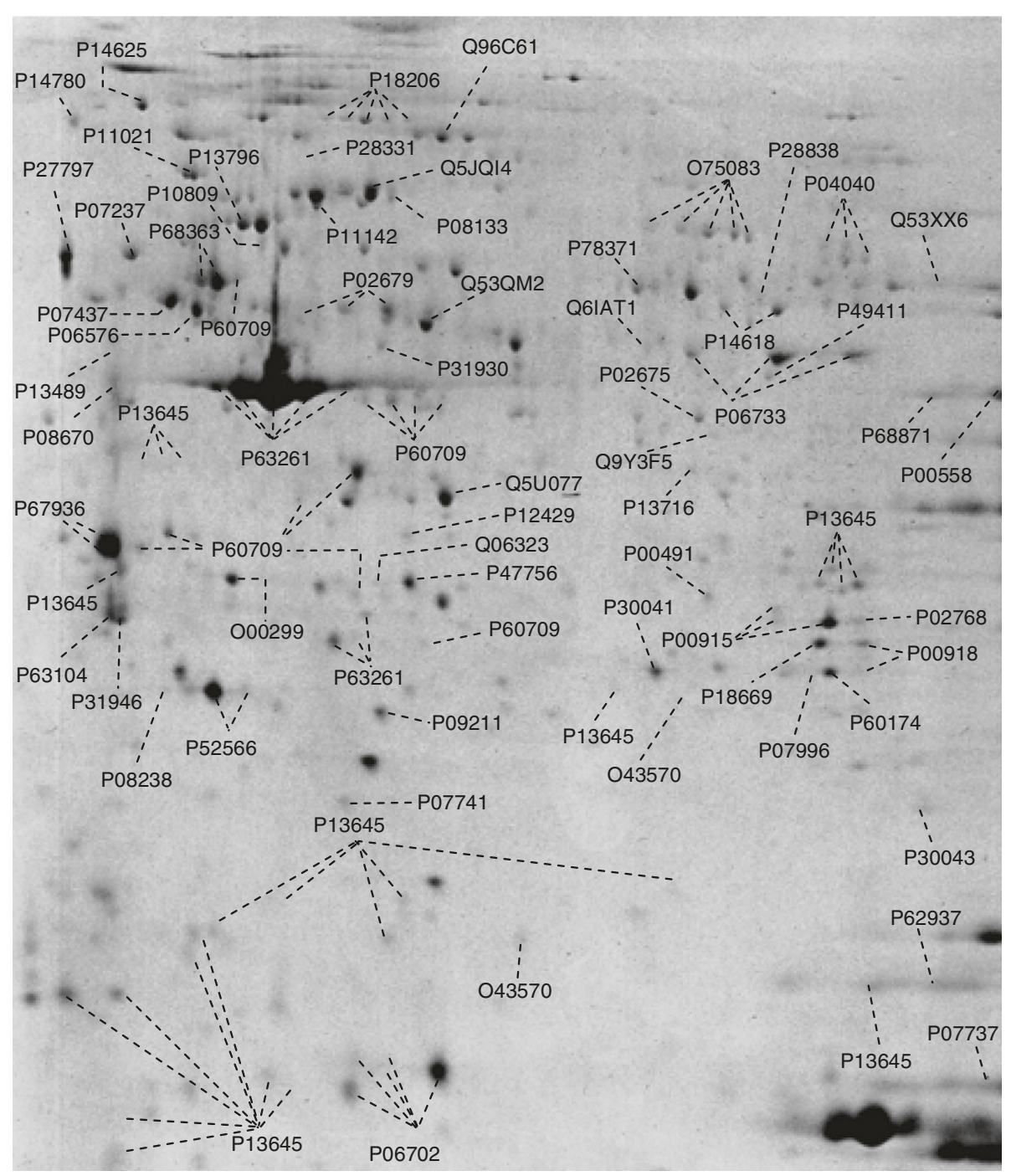

Figure 5 Protein mapping in circulating leucocytes of breast cancer patients; first-dimensional separation was performed in immobilised pH gradient (IPG) strips (Bio-Rad, USA) in the range of IP 4-7. Following first-dimensional separation, the extruded IPG-strips were equilibrated in gel equilibration buffer I (50 mM Tris- $\mathrm{HCl}, 6 \mathrm{M}$ urea, 30\% glycerol, 2\% SDS, 1\% DTT), followed by equilibration in buffer II (50 $\mathrm{mM}$ Tris-HCl, $6 \mathrm{M}$ urea, 30\% glycerol, 2\% SDS and $260 \mathrm{mM}$ iodacetamide) for $10 \mathrm{~min}$ before loading them onto polyacrylamide gels (12\% SDSPAGE) for the second-dimensional resolution in Mini-PROTEAN 3 (Bio-Rad). Altogether, 74 proteins were consequently identified by MALDI-TOF analysis; data taken from [11].

the biomarker panel of high predictive power in diagnosing of the breast cancer development.

\section{Group-specific versus individual therapy response: potential prognostic tool by proteomic blood tests?}

As it is summarised in Table 1, the reaction towards the standardised radiotherapy has been quantified at the level of the protein expression rates in circulating leucocytes. The resulting statistical analysis demonstrated following patterns: 14 proteins were significantly suppressed and 4 proteins were significantly induced in all patients tested. In contrast, further 4 proteins were individually (groupnon-significantly) suppressed and 2 proteins individually (group-non-significantly) induced. However, for the absolute majority (50) of the proteins measured strictly individual post-therapeutic regulation (up- / down or unchanged) was monitored. These findings motivates a creation of the "follow-up" projects to learn more about "molecular signature" of the patient beneficial therapy response as the potential prognostic tool.

What do we learn by the function of proteins involved in the breast cancer specific expression alterations in blood? Below listed groups (see Table 2) have been created according to the function(s) of individual proteins identified through the breast cancer specific profiles in circulating 


\begin{tabular}{|c|c|c|c|c|c|c|c|}
\hline Spot number & $\begin{array}{l}\text { Access } \\
\text { number }\end{array}$ & Accession name & Protein name & $\begin{array}{l}\text { Functional group } \\
\text { number }\end{array}$ & $\begin{array}{l}\text { Classification, references relevant for } \\
\text { functional groups } 19,20 \text { and } 21\end{array}$ & $\begin{array}{l}\text { Profile alterations } \\
\text { versus controls }\end{array}$ & $\begin{array}{l}\text { Alterations under } \\
\text { radio-therapy }\end{array}$ \\
\hline \multicolumn{8}{|c|}{ CATEGORY A: significantly $(\mathrm{T} \leq 0.1)$ altered expression profiles in patients versus controls } \\
\hline 112-116 & P04040 & CATA_HUMAN & Catalase & $\begin{array}{l}5,9,10,11,14,18 \\
\mathbf{1 9}, \mathbf{2 0}, \mathbf{2 1}\end{array}$ & $\begin{array}{l}\text { anti-oxidant defence and detoxification } \\
\text { protein [37-42] }\end{array}$ & $\begin{array}{l}\text { homogeneous suppression } \\
\downarrow 3 \mathrm{x} T=0,001\end{array}$ & Individual reaction $\uparrow \downarrow$ \\
\hline 157 & P07737 & PROF1_HUMAN & Profilin-1 & $1,2,11, \mathbf{1 9}, \mathbf{2 0}, 21$ & $\begin{array}{l}\text { Microfilamental network cell-migration } \\
\text { related protein }[11,43-48]\end{array}$ & $\begin{array}{l}\text { homogeneous } \\
\text { upregulation } \uparrow 4,0 \times \mathrm{T}=0,02\end{array}$ & $\begin{array}{l}\text { homogeneous } \\
\text { suppression } \downarrow \mathrm{T}=0,05\end{array}$ \\
\hline 23-27 & P63261 & ACTG_HUMAN & $\begin{array}{l}\text { Actin, cytoplasmic } 2 \\
\text { (Gamma-actin) }\end{array}$ & $\begin{array}{l}1,2,11,14,18, \mathbf{1 9} \\
\mathbf{2 0}, \mathbf{2 1}\end{array}$ & Microfilamental network protein [49-52] & $\begin{array}{l}\text { homogeneous suppression } \\
\downarrow 2 \times T=0,02\end{array}$ & Individual reaction $\uparrow \downarrow$ \\
\hline 124 & P27797 & CRTC_HUMAN & $\begin{array}{l}\text { Calreticulin precursor } \\
\text { CRP55 }\end{array}$ & $\begin{array}{l}2,11,12,17,18 \\
\mathbf{1 9}, \mathbf{2 0}, \mathbf{2 1}\end{array}$ & $\begin{array}{l}\text { Endoplasmic reticulum calcium-storage } \\
\text { protein regulating focal adhesion and cell } \\
\text { motility [53-60] }\end{array}$ & $\begin{array}{l}\text { homogeneous suppression } \\
\downarrow \\
2 \times \mathrm{T}=0,02\end{array}$ & Individual reaction $\uparrow \rightarrow$ \\
\hline 155 & P30043 & BLVRB_HUMAN & $\begin{array}{l}\text { Flavin reductase, NADHP- } \\
\text { dependent reductase }\end{array}$ & $3,6,9,11,18,19$ & Riboflavin biosynthesis pathway [61] & $\begin{array}{l}\text { individual induction } \\
\uparrow \mathrm{T}=0,02\end{array}$ & $\begin{array}{l}\text { homogeneous } \\
\text { induction } \uparrow \mathrm{T}=0,002\end{array}$ \\
\hline $70-74$ & P13645 & K1C10_HUMAN & $\begin{array}{l}\text { Keratin, type I } \\
\text { cytoskeletal } 10\end{array}$ & $\begin{array}{l}1,2,11,18, \mathbf{1 9} \\
\mathbf{2 0}, \mathbf{2 1}\end{array}$ & Microfilamental network protein [62-67] & $\begin{array}{l}\text { homogeneous induction } \\
\uparrow \mathrm{T}=0,03\end{array}$ & $\begin{array}{l}\text { homogeneous } \\
\text { suppression } \downarrow \mathrm{T}=0,1\end{array}$ \\
\hline 136 & 000299 & CLIC1_HUMAN & $\begin{array}{l}\text { Chloride intracellular } \\
\text { channel protein } 1\end{array}$ & $\begin{array}{l}8,11,14,19,20 \\
21\end{array}$ & $\begin{array}{l}\text { Channel, osmosis, } \mathrm{Ca}^{2+} \text {-dependent } \\
\text { apoptosis-related protein [68-71] }\end{array}$ & $\downarrow 2,5 \times T=0,04$ & Individual reaction $\uparrow \downarrow$ \\
\hline 156 & P08238 & HS90B_HUMAN & $\begin{array}{l}\text { Heat shock protein HSP } \\
\text { 90-beta }\end{array}$ & $\begin{array}{l}12, \mathbf{1 3}, 14,11,17 \\
18, \mathbf{1 9}, \mathbf{2 0}, \mathbf{2 1}\end{array}$ & Stress response protein [72-76] & $\begin{array}{l}\text { homogeneous suppression } \\
\downarrow 5 \mathrm{x} T=0,06\end{array}$ & $\begin{array}{l}\text { homogeneous } \\
\text { induction } \uparrow \mathrm{T}=0,02\end{array}$ \\
\hline 141 & P13489 & RINI_HUMAN & $\begin{array}{l}\text { Placental ribonuclease } \\
\text { inhibitor }\end{array}$ & $\begin{array}{l}3,9,12,14,17, \mathbf{2 0} \\
\mathbf{2 1}\end{array}$ & RNA/nucleotide turnover pathway [77-83] & $\begin{array}{l}\text { homogeneous suppression } \\
\downarrow 3 \mathrm{x} T=0,06\end{array}$ & $\begin{array}{l}\text { homogeneous } \\
\text { suppression } \downarrow T=0,1\end{array}$ \\
\hline 82 & P62937 & PPIA_HUMAN & $\begin{array}{l}\text { Peptidyl-prolyl cis-trans } \\
\text { isomerase A }\end{array}$ & $\begin{array}{l}4,11,12,14,17 \\
\mathbf{1 9}, \mathbf{2 0}, \mathbf{2 1}\end{array}$ & $\begin{array}{l}\text { Cyclophilin A is involved in protein folding, } \\
\text { assembly, transportation [84-89] }\end{array}$ & $\begin{array}{l}\text { homogeneous suppression } \\
\downarrow 3 \mathrm{x} T=0,06\end{array}$ & Individual reaction $\uparrow \rightarrow$ \\
\hline 28 & & & not identified protein & & & $\begin{array}{l}\text { highly upregulated in } \\
\text { several MKs } \mathrm{T}=0,06\end{array}$ & Individual reaction $\uparrow \downarrow$ \\
\hline 53 & & & not identified protein & & & $\begin{array}{l}\text { highly upregulated in } \\
\text { several MKs } \mathrm{T}=0,06\end{array}$ & Individual reaction $\uparrow \downarrow$ \\
\hline 142 & P08670 & VIME_HUMAN & Vimentin & $\begin{array}{l}1,2,11,14,18, \mathbf{1 9} \\
\mathbf{2 0}, \mathbf{2 1}\end{array}$ & $\begin{array}{l}\text { Microfilamental network cell-migration } \\
\text { related protein }[60,76,90-97]\end{array}$ & $\downarrow 2 \times T=0,09$ & Individual reaction $\boldsymbol{\uparrow} \rightarrow$ \\
\hline $62,8593-95$ & P00915 & CAH1_HUMAN & Carbonic anhydrase I & $\begin{array}{l}5,11,18 \mathbf{1 9}, \mathbf{2 0} \\
\mathbf{2 1}\end{array}$ & Energy metabolism related protein [98-104] & $\downarrow 2 \times T=0,10$ & Individual reaction $\uparrow \downarrow$ \\
\hline 143 & P28838 & AMPL_HUMAN & Cytosol aminopeptidase & $\begin{array}{l}4,11,14 \mathbf{1 9}, \mathbf{2 0} \\
\mathbf{2 1}\end{array}$ & $\begin{array}{l}\text { Regulatory protein-modification enzyme } \\
\text { [105-109] }\end{array}$ & $\begin{array}{l}\text { individual induction } \uparrow \\
T=0,1\end{array}$ & $\begin{array}{l}\text { homogeneous } \\
\text { suppression } \downarrow T=0,1\end{array}$ \\
\hline 135 & P49411 & EFTU_HUMAN & $\begin{array}{l}\text { Elongation factor Tu, } \\
\text { mitochondrial precursor }\end{array}$ & 7,20 & $\begin{array}{l}\text { Mitochondrial protein synthesis machinery, } \\
\text { critical role to maintain the translational } \\
\text { fidelity }[110,111]\end{array}$ & $\begin{array}{l}\text { homogeneous suppression } \\
\downarrow 4 \times \mathrm{x}=0,1\end{array}$ & Individual reaction $\uparrow \rightarrow$ \\
\hline $45-46$ & P52566 & GDIS_HUMAN & $\begin{array}{l}\text { Rho GDP-dissociation } \\
\text { inhibitor } 2 \text { (Rho GDIß) }\end{array}$ & $\begin{array}{l}1,2,11,12,14,17 \\
\mathbf{1 9}, \mathbf{2 0}, \mathbf{2 1}\end{array}$ & $\begin{array}{l}\text { LyDGI plays a role in the onset of apoptosis } \\
\text { and cell migration }[11,112-116]\end{array}$ & $\begin{array}{l}\text { homogeneous } \\
\text { upregulation } \uparrow \mathrm{T}=0,1\end{array}$ & Individual reaction $\uparrow \downarrow$ \\
\hline
\end{tabular}




\begin{tabular}{|c|c|c|c|c|c|c|c|}
\hline 148 & P63104 & 1433Z_HUMAN & $\begin{array}{l}\text { 14-3-3 protein zeta/delta } \\
\text { (protein kinase } C \text { inhibitor) }\end{array}$ & $\begin{array}{l}11,12,14,17,18 \\
\mathbf{1 9}, \mathbf{2 0}, \mathbf{2 1}\end{array}$ & $\begin{array}{l}\text { Cell-cycle checkpoint, stress response } \\
\text { protein [117-119] }\end{array}$ & $\begin{array}{l}\text { homogeneous suppression } \\
\downarrow 2,5 \times \mathrm{x}=0,1\end{array}$ & $\begin{array}{l}\text { homogeneous } \\
\text { suppression } \downarrow \mathrm{T}=0,001\end{array}$ \\
\hline 67 & P06702 & S10A9_HUMAN & $\begin{array}{l}\text { Protein S100-A9, } \\
\text { Calgranulin }\end{array}$ & $\begin{array}{l}2,11,14,18, \mathbf{1 9} \\
\mathbf{2 0}, \mathbf{2 1}\end{array}$ & $\begin{array}{l}\mathrm{Ca}^{2+} \text {-dependent cell-migration related } \\
\text { protein }[11,120-127]\end{array}$ & $\uparrow 2,5 \times \mathrm{T}=0,11$ & $\begin{array}{l}\text { Individual reaction } \uparrow \rightarrow \\
\downarrow\end{array}$ \\
\hline 110 & & & not identified protein & & & $\begin{array}{l}\text { highly upregulated in } \\
\text { several } \mathrm{MKs} \mathrm{T}=0,11\end{array}$ & Individual reaction $\uparrow \downarrow$ \\
\hline 123 & P07237 & PDIA1_HUMAN & $\begin{array}{l}\text { Protein disulfide- } \\
\text { isomerase precursor, PDI }\end{array}$ & $\begin{array}{l}4,14,9,17,18, \mathbf{2 0} \\
\mathbf{2 1}\end{array}$ & $\begin{array}{l}\text { Stress-related protein modification enzyme } \\
{[60,128-131]}\end{array}$ & $\downarrow 2,5 \times \mathrm{x}=0,12$ & Individual reaction $\uparrow \downarrow$ \\
\hline 104 & & & not identified protein & & & $\begin{array}{l}\text { highly upregulated in } \\
\text { several MKs } \mathrm{M}=0,12\end{array}$ & Individual reaction $₫ \downarrow$ \\
\hline \multicolumn{8}{|c|}{ CATEGORY B: non-significantly altered expression profiles in patients versus controls } \\
\hline 131 & P78371 & TCPB_HUMAN & $\begin{array}{l}\text { T-complex protein } 1 \\
\text { subunit beta }\end{array}$ & $4, \mathbf{2 0}, 21$ & A member of chaperons family $[132,133]$ & $\begin{array}{l}\text { individual upregulation } \boldsymbol{\uparrow} \\
2 \times \mathrm{T}=0,15\end{array}$ & $\begin{array}{l}\text { homogeneous } \\
\text { suppression } \downarrow \mathrm{T}=0,05\end{array}$ \\
\hline 19-21, 39 & P60709 & ACTB_HUMAN & $\begin{array}{l}\text { Actin, cytoplasmic } 1 \\
\text { (Beta-actin) }\end{array}$ & $\begin{array}{l}1,2,11,14,18, \mathbf{1 9} \\
\mathbf{2 0}, \mathbf{2 1}\end{array}$ & Microfilamental network protein [11] & $\begin{array}{l}\text { slightly increased } \mathbf{T} \\
1,5 \times T=0,16\end{array}$ & Individual reaction $\uparrow \rightarrow$ \\
\hline 97 & P60174 & TPIS_HUMAN & $\begin{array}{l}\text { Triosephosphate } \\
\text { isomerase }\end{array}$ & $5,7,19,20,21$ & $\begin{array}{l}\text { Energy metabolism related protein } \\
\text { [134-137] }\end{array}$ & $\begin{array}{l}\text { individual upregulation } \mathbf{\uparrow} \\
2 \mathrm{x} T=0,2\end{array}$ & Individual reaction $\uparrow \downarrow$ \\
\hline 44 & & ANXA1-HUMAN & Annexin A1 (Calpactin II) & $\begin{array}{l}9,11,14,17,18 \\
19,20,21\end{array}$ & $\begin{array}{l}\mathrm{Ca}^{2+} \text {-dependent phospholipid-binding } \\
\text { proteins, potential anti-inflammatory } \\
\text { activity [138-141] }\end{array}$ & $\begin{array}{l}\text { individual upregulation } \boldsymbol{\uparrow} \\
2 \times \mathrm{T}=0,2\end{array}$ & $\begin{array}{l}\text { homogeneous } \\
\text { induction } \uparrow \mathrm{T}=0,1\end{array}$ \\
\hline 80 & P05109 & S10A8_HUMAN & $\begin{array}{l}\text { Protein S100-A8, } \\
\text { Calgranulin }\end{array}$ & $\begin{array}{l}2,11,14,18, \mathbf{1 9} \\
\mathbf{2 0}, \mathbf{2 1}\end{array}$ & $\begin{array}{l}\mathrm{Ca}^{2+} \text {-dependent cell-migration / tumour } \\
\text { related protein }[11,120-127]\end{array}$ & homogeneous $\uparrow 2,0 \times \mathrm{x}=0,24$ & Individual suppression $\downarrow$ \\
\hline 37 & P47756 & CAPZB_HUMAN & $\begin{array}{l}\text { F-actin-capping protein } \\
\text { subunit beta (CapZ beta) }\end{array}$ & $\begin{array}{l}1,2,11,14,18, \mathbf{1 9} \\
\mathbf{2 0}, \mathbf{2 1}\end{array}$ & Microfilamental network protein [142-145] & slightly increased $\mathbf{\uparrow} \mathrm{T}=0,2$ & Individual reaction $₫ \downarrow \downarrow$ \\
\hline 137 & P30041 & PRDX6_HUMAN & Peroxiredoxin-6 & $\begin{array}{l}9,10,11,14,17 \\
18, \mathbf{1 9}, \mathbf{2 0}, \mathbf{2 1}\end{array}$ & $\begin{array}{l}\text { Multifuctional anti-oxidant, defence, tumour- } \\
\text { invasion and metastases related protein } \\
\text { [146-150] }\end{array}$ & slightly increased $\mathrm{T}=0,2$ & Individual reaction $₫ \downarrow \downarrow$ \\
\hline $9-11$ & P02679 & FIBG_HUMAN & Fibrinogen gamma chain & $11,17, \mathbf{1 9}, \mathbf{2 0}, \mathbf{2 1}$ & $\begin{array}{l}\text { Microfilamental network cell-migration } \\
\text { related protein [151-157] }\end{array}$ & homogeneous $\uparrow 1,5 \times T=0,24$ & Individual reaction $\uparrow \rightarrow$ \\
\hline 130 & P10809 & CH60_HUMAN & 60 kDa heat shock protein & $\begin{array}{l}4,5,7,11,13,17 \\
\mathbf{1 9}, \mathbf{2 0}, \mathbf{2 1}\end{array}$ & $\begin{array}{l}\text { Mitochondrial stress response protein, } \\
\text { protein-folding [158-166] }\end{array}$ & $\begin{array}{l}\text { slightly increased } \\
\text { homogeneous level } T=0,25\end{array}$ & $\begin{array}{l}\text { homogeneous } \\
\text { suppression } \downarrow \mathrm{T}=0,1\end{array}$ \\
\hline 36 & Q5U077 & Q5U077_HUMAN & L-lactate dehydrogenase B & $\begin{array}{l}5,7,11, \mathbf{1 9}, \mathbf{2 0} \\
\mathbf{2 1}\end{array}$ & $\begin{array}{l}\text { Energy metabolism related protein } \\
{[134,167-172]}\end{array}$ & slightly increased $\mathbf{\uparrow} 1,5 \mathrm{x}$ & Individual reaction $\uparrow \downarrow$ \\
\hline 122 & Q96C61 & Q96C61_HUMAN & FLNA protein & $\begin{array}{l}1,2,11,14, \mathbf{1 9} \\
\mathbf{2 0}, \mathbf{2 1}\end{array}$ & $\begin{array}{l}\text { Filamin A - actin binding protein has essential } \\
\text { role in intercellular junctions [173-178] }\end{array}$ & homogeneous $\uparrow 1,5 x$ & Individual reaction $₫ \downarrow \downarrow$ \\
\hline 151 & P07996 & TSP1_HUMAN & $\begin{array}{l}\text { Thrombospondin-1 } \\
\text { precursor }\end{array}$ & $\begin{array}{l}2,15,11,14,17 \\
\mathbf{1 9}, \mathbf{2 0}, \mathbf{2 1}\end{array}$ & $\begin{array}{l}\text { The matricellular protein regulating cell } \\
\text { adhesion and motility during tissue } \\
\text { remodelling, in fibrogenesis \& angiogenesis } \\
\text { [179-189] }\end{array}$ & $\begin{array}{l}\text { Individual induction } \mathbf{T} \\
\mathrm{T}=0,29\end{array}$ & Individual reaction $₫ \downarrow$ \\
\hline
\end{tabular}


Table 1 Protein profile alterations in breast cancer and under radiotherapy (Continued)

\begin{tabular}{|c|c|c|c|c|c|c|c|}
\hline \multicolumn{8}{|c|}{ CATEGORY C: individual group-heterogeneous expression profiles in patients versus homogeneous one in controls } \\
\hline 86,87 & P00918 & CAH2_HUMAN & Carbonic anhydrase II & $\begin{array}{l}5,11,18, \mathbf{1 9}, \mathbf{2 0} \\
\mathbf{2 1}\end{array}$ & $\begin{array}{l}\text { Energy metabolism related protein } \\
{[98-100,103,104,190,191]}\end{array}$ & Individual heterogeneous & Individual reaction $\uparrow \downarrow$ \\
\hline 103 & P02675 & FIBB_HUMAN & $\begin{array}{l}\text { Fibrinogen beta chain } \\
\text { precursor }\end{array}$ & $11,17, \mathbf{1 9}, \mathbf{2 0}, \mathbf{2 1}$ & $\begin{array}{l}\text { Microfilamental network cell-migration } \\
\text { related protein [151-157] }\end{array}$ & Individual heterogeneous & Individual reaction $\uparrow \rightarrow$ \\
\hline $117-120$ & 075083 & WDR1_HUMAN & $\begin{array}{l}\text { WD repeat-containing } \\
\text { protein } 1\end{array}$ & $4,12,11,14,20$ & $\begin{array}{l}\text { Cell-cycle and proteolytic machinery } \\
\text { related protein [189,192] }\end{array}$ & Individual heterogeneous & Individual reaction $\uparrow \rightarrow$ \\
\hline 126 & P28331 & NUAM_HUMAN & $\begin{array}{l}\text { NADH-ubiquinone } \\
\text { oxidoreductase } 75 \mathrm{kDa}\end{array}$ & $\begin{array}{l}5,7,9,11,14, \mathbf{1 9} \\
\mathbf{2 0}, \mathbf{2 1}\end{array}$ & $\begin{array}{l}\text { Mitochondrial energy metabolism related } \\
\text { protein [193-197] }\end{array}$ & highly heterogeneous & Individual reaction $\uparrow \downarrow$ \\
\hline 127 & P08133 & ANXA6_HUMAN & Annexin A6 (P70) & $\begin{array}{l}2,8,11,14,16,17 \\
\mathbf{1 9}, \mathbf{2 0}, \mathbf{2 1}\end{array}$ & $\begin{array}{l}\text { Membrane architecture and signalling } \\
\text { protein }[127,198-201]\end{array}$ & Individual induction & Individual induction $\mathbf{\uparrow}$ \\
\hline 128 & P11142 & HSP7C_HUMAN & $\begin{array}{l}\text { Heat shock cognate } 71 \\
\text { kDa protein }\end{array}$ & $\begin{array}{l}4,5,11,13,14,17 \\
18, \mathbf{1 9}, \mathbf{2 0}, \mathbf{2 1}\end{array}$ & $\begin{array}{l}\text { Stress response protein,chaperone, ATPase } \\
{[202-206]}\end{array}$ & Individual heterogeneous & Individual reaction $\uparrow \rightarrow$ \\
\hline 144 & Q53XX6 & ATPA_HUMAN & $\begin{array}{l}\text { ATP-synthase, } \mathrm{H}+ \\
\text { transporting } \\
\text { mitochondrial protein }\end{array}$ & $\begin{array}{l}5,7,8,11,18, \mathbf{1 9} \\
\mathbf{2 0}, \mathbf{2 1}\end{array}$ & $\begin{array}{l}\text { Mitochondrial energy metabolism related } \\
\text { protein [207-212] }\end{array}$ & Individual heterogeneous & Individual reaction $\uparrow \downarrow$ \\
\hline 147 & P31946 & 1433B_HUMAN & $\begin{array}{l}\text { 14-3-3 protein beta/ } \\
\text { alpha (protein- kinase-C } \\
\text { inhibitor) }\end{array}$ & $\begin{array}{l}4,11,12,14,17 \\
19,20,21\end{array}$ & $\begin{array}{l}\text { Cell-cycle checkpoint, stress response } \\
\text { protein }[118,213-216]\end{array}$ & highly heterogeneous & $\begin{array}{l}\text { homogeneous } \\
\text { suppression } \downarrow T=0,001\end{array}$ \\
\hline 152 & P14780 & MMP9_HUMAN & Matrix metalloproteinase-9 & $\begin{array}{l}11,14,15,18, \mathbf{1 9} \\
\mathbf{2 0}, \mathbf{2 1}\end{array}$ & $\begin{array}{l}\text { MMP9 Multifunctional tissue-remodeling } \\
\text { protein [217-222] }\end{array}$ & highly heterogeneous & Individual reaction $\uparrow \downarrow$ \\
\hline \multicolumn{8}{|c|}{ CATEGORY D: similar expression-profiles among patients and controls } \\
\hline $1-5$ & P18206 & VINC_HUMAN & & Vinculin & Cytoskeletal assembly associated protein & similar & Individual reaction $\uparrow \downarrow$ \\
\hline $\begin{array}{l}6-8,17,34 \\
38,63,105 \\
109,111\end{array}$ & & & & $\begin{array}{l}\text { not identified } \\
\text { protein spots }\end{array}$ & & similar & Individual reaction $\uparrow \downarrow$ \\
\hline $\begin{array}{l}12,13,32,33 \\
43,47,48,98\end{array}$ & P60709 & ACTB_HUMAN & & $\begin{array}{l}\text { Actin, cytoplasmic } \\
1 \text { (Beta-actin) }\end{array}$ & Microfilamental network protein & similar & Individual reaction $\uparrow \downarrow$ \\
\hline 14-15 & P68363 & TBA1B_HUMAN & & $\begin{array}{l}\text { Tubulin alpha- } \\
\text { chain }\end{array}$ & Microtubule network protein & similar & Individual reaction $\uparrow \downarrow$ \\
\hline 16 & P06576 & ATPB_HUMAN & & $\begin{array}{l}\text { ATP synthase } \\
\text { subunit beta, } \\
\text { mitochondrial } \\
\text { precursor }\end{array}$ & $\begin{array}{l}\text { Mitochondrial energy metabolism related } \\
\text { protein }\end{array}$ & similar & Individual reaction $\uparrow \downarrow$ \\
\hline 18 & P07437 & TBB2_HUMAN & & $\begin{array}{l}\text { Tubulin beta-2 } \\
\text { chain }\end{array}$ & Microfilamental network protein & similar & Individual reaction $\uparrow \rightarrow$ \\
\hline $\begin{array}{l}29-31,51,52,1 \\
54-61,64,79 \\
81,83,84, \\
89-92\end{array}$ & P13645 & K1C10_HUMAN & & $\begin{array}{l}\text { Keratin, type I } \\
\text { cytoskeletal } 10\end{array}$ & Microfilamental network protein & similar & Individual reaction $\uparrow \downarrow$ \\
\hline
\end{tabular}


Table 1 Protein profile alterations in breast cancer and under radiotherapy (Continued)

\begin{tabular}{|c|c|c|c|c|c|c|}
\hline 40,41 & P63261 & ACTG_HUMAN & $\begin{array}{l}\text { Actin, cytoplasmic } \\
2 \text { (Gamma-actin) }\end{array}$ & Microfilamental network protein & similar & Individual reaction $\uparrow \downarrow$ \\
\hline 42 & & Q6FHP5_HUMAN & PHB protein & $\begin{array}{l}\text { Prohibitin - negative regulator of cell } \\
\text { proliferation and may be a tumor } \\
\text { suppressor. Mutations in PHB have been } \\
\text { linked to sporadic breast cancer. }\end{array}$ & similar & $\begin{array}{l}\text { homogeneous } \\
\text { suppression } \downarrow\end{array}$ \\
\hline $49-50$ & P67936 & TPM4_HUMAN & $\begin{array}{l}\text { Tropomyosin } \\
\text { alpha-4 chain }\end{array}$ & Microfilamental network protein & similar & Individual reaction $\uparrow \downarrow$ \\
\hline 88 & P02768 & ALBU_HUMAN & Serum albumin & Extracellular transport/carrier protein & similar & Individual reaction $\uparrow \downarrow$ \\
\hline 96 & P18669 & PGAM1_HUMAN & $\begin{array}{l}\text { Phosphoglycerate } \\
\text { mutase } 1\end{array}$ & Energy metabolism related protein & similar & $\begin{array}{l}\text { homogeneous } \\
\text { suppression } \downarrow \mathrm{T}=0,1\end{array}$ \\
\hline 99 & P00558 & PGK1_HUMAN & $\begin{array}{l}\text { Phosphoglycerate } \\
\text { kinase } 1\end{array}$ & Energy metabolism related protein & similar & Individual reaction $\uparrow \rightarrow$ \\
\hline 100 & P68871 & HBB_HUMAN & $\begin{array}{l}\text { Hemoglobin } \\
\text { subunit beta }\end{array}$ & Oxygen carrier & similar & Individual reaction $\uparrow \downarrow$ \\
\hline $101,102,106$ & P06733 & ENOA_HUMAN & Alpha-enolase & multifunctional glycolytic enzyme & similar & Individual reaction $\uparrow \rightarrow$ \\
\hline 107 & P14618 & KPYM_HUMAN & $\begin{array}{l}\text { Pyruvate kinase, } \\
\text { isozymes M1/M2 }\end{array}$ & Energy metabolism related protein & similar & Individual reaction $\uparrow \rightarrow$ \\
\hline 125 & P14625 & ENPL_HUMAN & $\begin{array}{l}\text { Endoplasmin } \\
\text { precursor }(94-\mathrm{kDa} \\
\text { glucose-regulated } \\
\text { protein) }\end{array}$ & $\begin{array}{l}\text { Signal transduction pathways associated } \\
\text { with endoplasmic reticulum stress }\end{array}$ & similar & $\begin{array}{l}\text { homogeneous } \\
\text { suppression } \downarrow \mathrm{T}=0,1\end{array}$ \\
\hline 129 & P13796 & PLSL_HUMAN & Plastin-2 & Microfilamental network protein & similar & $\begin{array}{l}\text { homogeneous } \\
\text { suppression } \downarrow \mathrm{T}=0,02\end{array}$ \\
\hline 132 & Q53QM2 & Q53QM2_HUMAN & $\begin{array}{l}\text { Hypothetical } \\
\text { protein ACTR3 }\end{array}$ & Currently uncharacterized protein & similar & $\begin{array}{l}\text { homogeneous } \\
\text { suppression } \downarrow \mathrm{T}=0,1\end{array}$ \\
\hline 133 & Q6IAT1 & Q6IAT1_HUMAN & $\begin{array}{l}\text { GDI2 protein (GDP } \\
\text { dissociation } \\
\text { inhibitor 2) }\end{array}$ & $\begin{array}{l}\text { Regulatory protein in the functional } \\
\text { cycle and recycling of Rab GTPases }\end{array}$ & similar & Individual suppression $\downarrow$ \\
\hline 134 & & UQCR1_HUMAN & $\begin{array}{l}\text { Reductase } \\
\text { complex core } \\
\text { protein I }\end{array}$ & $\begin{array}{l}\text { Ubiquinol-cytochrome C- reductase, } \\
\text { mitochondrial processing peptidase } \\
\text { Beta-family }\end{array}$ & similar & Individual reaction $\uparrow \downarrow$ \\
\hline 138 & P09211 & GSTP1_HUMAN & $\begin{array}{l}\text { Glutathione S- } \\
\text { transferase P (GST } \\
\text { class-pi) }\end{array}$ & $\begin{array}{l}\text { Stress response and anti-oxidant } \\
\text { defence protein }\end{array}$ & similar & $\begin{array}{l}\text { homogeneous } \\
\text { induction } \uparrow \mathrm{T}=0,07\end{array}$ \\
\hline 139 & P07741 & APT_HUMAN & $\begin{array}{l}\text { Adenine } \\
\text { phosphoribosyl- } \\
\text { transferase }\end{array}$ & Nucleotide metabolism & similar & Individual reaction $\uparrow \rightarrow$ \\
\hline 140 & P11021 & GRP78_HUMAN & $\begin{array}{l}78 \mathrm{kDa} \text { glucose- } \\
\text { regulated protein } \\
\text { precursor (GRP 78) }\end{array}$ & Energy metabolism related protein & similar & Individual reaction $\uparrow \rightarrow$ \\
\hline
\end{tabular}


Table 1 Protein profile alterations in breast cancer and under radiotherapy (Continued)

\begin{tabular}{|c|c|c|c|c|c|c|}
\hline$\overline{145}$ & P13716 & HEM2_HUMAN & $\begin{array}{l}\text { Delta- } \\
\text { aminolevulinic } \\
\text { acid dehydratase }\end{array}$ & $\begin{array}{l}\text { anti-oxidant defence and detoxification } \\
\text { pathways }\end{array}$ & similar & $\begin{array}{l}\text { homogeneous } \\
\text { suppression } \downarrow \mathrm{T}=0,07\end{array}$ \\
\hline 146 & Q5JQ14 & HSP71_HUMAN & $\begin{array}{l}\text { Heat shock } 70 \mathrm{kDa} \\
\text { protein } 1 \mathrm{~A}\end{array}$ & Stress response protein & similar & Individual reaction $₫ \downarrow \downarrow$ \\
\hline 149 & Q06323 & PSME1_HUMAN & $\begin{array}{l}\text { Proteasome } \\
\text { activator complex } \\
\text { subunit } 1\end{array}$ & $\begin{array}{l}\text { The activator binds to proteasome } 205 \text { \& } \\
\text { enhances peptidase activity, e.g. under } \\
\text { stress conditions }\end{array}$ & similar & Individual reaction $\uparrow \downarrow$ \\
\hline 150 & P00491 & PNPH_HUMAN & $\begin{array}{l}\text { Purine nucleoside } \\
\text { phosphorylase }\end{array}$ & $\begin{array}{l}\text { Nucleotide- and nucleoside turnover, } \\
\text { detoxification pathway }\end{array}$ & similar & Individual suppression $\downarrow$ \\
\hline 153 & P12429 & ANXA3_HUMAN & Annexin A3 & $\begin{array}{l}\text { Membrane architecture and signalling } \\
\text { protein }\end{array}$ & similar & Individual reaction $\uparrow \rightarrow$ \\
\hline 154 & & VDAC1_HUMAN & $\begin{array}{l}\text { Voltage- } \\
\text { dependent anion- } \\
\text { selective channel } \\
\text { protein } 1\end{array}$ & $\begin{array}{l}\text { Membrane protein, regulation of cell } \\
\text { growth / death via redox-control }\end{array}$ & similar & Individual induction $\boldsymbol{\uparrow}$ \\
\hline 158 & & Q9Y3F5_HUMAN & $\begin{array}{l}\text { A6-related } \\
\text { hypothetical } \\
\text { protein }\end{array}$ & $\begin{array}{l}\text { Twinfilin-2, Protein tyrosine kinase 9-like, } \\
\text { actin-binding protein involved in motile and } \\
\text { morphological processes }\end{array}$ & similar & $\begin{array}{l}\text { Homogeneous } \\
\text { suppression } \downarrow \mathrm{T}=0,1\end{array}$ \\
\hline
\end{tabular}

Annotation to Table 1: 158 spots have been distinguished by protein mapping as stably expressed (i.e. by all members of the group) in circulating leucocytes of the group with breast cancer patients. Altogether 74 proteins have been identified within 158 spots. The protein mapping image is demonstrated in Figure 5. The spot number in the map (Spot number) and corresponding accession number (Access number) and name (Accession name) received from the SwissProt database is provided in the table together with the name of the identified protein (Protein name) in accordance with the current protein nomenclature. The column "Classification" provides information about the function(s) currently known for each protein. The corresponding number of the functional group(s) is/are provided in the column "Functional group number"; the designation of the functional group with the corresponding number can be found in the separate Table 2 . The regulation manner (up / down regulation) and the severity of the expression profile alterations under the cancer condition have been qualified and quantified versus the values in the control group; the resulting information is provided in the column "Profile alterations versus controls". In accordance to the expression profile alterations, every mapped protein has been assigned to one of the altogether four CATEGORIES built-up as follows: A $=22$ proteins with the statistically significant alterations in the expression profiles under the cancer condition compared to the control group $(T \leq 0,1) ; B=12$ with the statistically non-significant alterations in the expression profiles under the cancer condition compared to the control group; $\mathrm{C}=9$ proteins with the expression profiles altered individually with highly heterogeneous expression profiles within the patient group versus stable expression levels within the control group; $\mathrm{D}=31$ proteins with similar expression-profiles within both patient and control groups of comparison. Further, under the cancer condition, the expression alterations as the reaction towards the applied radiotherapy has been qualified (up / down regulation) and quantified as it is summarised for each protein in the column "Alterations under radiotherapy". The resulting statistics is provided here: 14 proteins homogeneously (group-significantly) suppressed ( $\mathfrak{l}$ ), 4 proteins homogeneously (group-significantly) induced ( $\mathbf{T}$ ), 4 proteins individually (group-non-significantly) suppressed ( $\mathfrak{l}$ ), 2 proteins individually (group-non-significantly) induced ( $\mathbf{T}$ ), 33 individually up- or down-regulated proteins $(\mathbf{T} \downarrow$ ), and 17 proteins with individual up-/or down-/or unchanged regulation $(\mathbf{\uparrow} \rightarrow \mathfrak{\downarrow}$ ) have been profiled under radiotherapy. 
Table 2 Systematic overview of the integrative panel of proteins/functional groups involved in the breast cancer specific molecular patterns in blood cells

\begin{tabular}{|c|c|c|c|}
\hline Nr. & Functional group & $\begin{array}{l}\text { Relevance for breast cancer } \\
\text { in tissue [reference] }\end{array}$ & $\begin{array}{l}\text { Relevance for breast } \\
\text { cancer in blood [reference] }\end{array}$ \\
\hline 1 & $\begin{array}{l}\text { microfilamental network-associated and cytoskeletal-assembly } \\
\text { proteins }\end{array}$ & {$[48,223,224]$} & [11] \\
\hline 2 & cell motility, migration \& adhesion & {$[225-227]$} & [11] \\
\hline 3 & nucleoside / nucleotide turnover \& metabolism & {$[228,229]$} & \\
\hline 4 & $\begin{array}{l}\text { protein metabolism (regulatory protein-synthesis \& protein- } \\
\text { modification enzymes, chaperons) }\end{array}$ & {$[230,231]$} & [231] \\
\hline 5 & energy metabolism & [232-236] & {$[232,236]$} \\
\hline 6 & vitamin metabolism & {$[237,238]$} & \\
\hline 7 & mitochondrial proteins & {$[239-241]$} & {$[239,241]$} \\
\hline 8 & channels, membrane-architecture and intercellular-junction proteins & {$[242]$} & \\
\hline 9 & anti-oxidant defence / red-ox control & [243-246] & [245] \\
\hline 10 & detoxification proteins & {$[247]$} & \\
\hline 11 & stress-response / -protection related protein & {$[75,248-250]$} & \\
\hline 12 & cell-cycle machinery proteins & {$[251-253]$} & \\
\hline 13 & heat-shock proteins & [254-258] & \\
\hline 14 & apoptosis-related proteins / protection against apoptosis & {$[259-261]$} & {$[262,263]$} \\
\hline 15 & tissue-remodelling enzymes & {$[21,264-268]$} & \\
\hline 16 & extra-cellular transport \& carrier-proteins & {$[258,269,270]$} & \\
\hline 17 & signal-transduction proteins / signalling pathways & {$[271-274]$} & \\
\hline 18 & longevity / ageing related proteins & {$[275-278]$} & \\
\hline 19 & inflammation related / anti-inflammatory proteins & {$[14,21,279]$} & \\
\hline 20 & (breast) cancer related inhibitor / promoter & $\begin{array}{l}\text { see references to individual proteins listed } \\
\text { in the Table } 1\end{array}$ & \\
\hline 21 & cancer invasion and regulator of metastases formation & $\begin{array}{l}\text { see references to individual proteins listed } \\
\text { in Table } 1\end{array}$ & \\
\hline
\end{tabular}

leucocytes (see Table 1). The literature sources relevant for the issue are listed in the Table 1 respectively to the functional groups. What do we learn from the exercise?

$>$ According to the content summarised in the Table 2, it is evident that the breast cancer specific protein profiles affect a spectrum of the central biological activities in and of the cell.

$\triangleright$ The multifactorial impacts of the disease are evident.

$\triangleright$ Certainly there are effective interactions among individual functional groups: several proteins are involved and play a (key) role at least in two but frequently in a much higher number of the functional groups listed.

$\triangleright$ All the proteins with expression rates altered under the breast cancer condition as described in this article, have been reported to stay in a kind of relation to cancer / breast cancer / metastatic activity. Moreover, some of the combinations of the proteins presented here have been already reported in relation to breast/cancer. $\triangleright$ However, the particular value of this article is in the systematic overview of the integrative panel of proteins/functional groups involved in the breast cancer specific molecular patterns in blood cells.

$\triangleright$ Furthermore, the tool is obviously of high importance in favour of non-invasive prediction of breast cancer, since only very few literature sources could be found for breast cancer blood biomarker/patterns.

Personalised treatments of the manifested breast cancer: where are we now?

During the last years several biomarkers as well as molecular factors have made their way into clinical routine. Extensive translational research, new mathematical models and computer-based analysis resulted in validated markers that allow personalised decision making for each individual patient already nowadays. Below we summarise the actualities and factors that have recently been shown to provide additional prognostic or predictive information and can finally spare ineffective or even harmful treatments (e.g. chemotherapy) and promote approaches tailored to the patient. 
Clinicopathological factors, such as the histological subtype, tumour grade as well as the expression of the receptors for oestrogen, progesterone and HER2 belong to the most established evidence for making decisions over individualised therapeutic approaches. Therefrom, the expression levels of oestrogen receptor and HER2 are currently the best known predictive and prognostic biomarkers for individualised breast cancer therapy [280]. Increased expression rates of HER2 is the valid biomarker for an unfavourable prognosis in breast cancer management [281,282]. Furthermore, retrospective studies revealed a functional link between the level of HER2 expression and an individual patient response towards endocrine therapy and sensitivity to taxanes and anthracyclines [283-285]. However, the highest impact of HER2 in the clinical practice is its predictive and prognostic value indicating a response to trastuzumab and pertuzumab as well as to lapatinib (an inhibitor of the tyrosine kinase domain within HER1 and HER2 sequences) [286-288].

Further, a potential clinical utilisation of novel biomarkers dealing with the enzymatic complexes of cell proliferation, such as ki67 and uPA/PAI-1, is on the horizon. Hence, an elevated expression of ki67 is a potent marker for aggressive tumour types and a consequently poor prognosis [289,290]. Several studies demonstrated an association of ki67 expressional level with the quality of patient response towards chemotherapy and endocrine therapy [291,292]. Consequently, ki67 has been included into the St. Gallen Consensus Recommendations to stratify breast tumours according to the level of proliferation [293]. In primary breast cancer, independent prognostic factors UPA/PAI-1 indicates a level of the tumour invasion and metastatic disease that is of particular value for treatments of the node-negative breast cancer [294,295]. Both factors have reached highest level of evidence (LOI-1) and have been recommended for the classification of the groups of risk in making decisions for treatments of the node-negative breast cancer [296,297].

The central role in creating an individual risk profile receives the computer assistance. For example, Adjuvant! Online is an internet-based algorithm aiming at prediction of the recurrence free survival and total survival over 10 years [298]. This programme takes into consideration the best established clinical and pathology-specific contributing risk factors such as tumour size, nodal involvement, histology, hormone receptor status and age in combination with co-morbidities registered. Adjuvant!Online may be potentially utilised to prognose individual risks and benefits of endocrine therapy and / or variants of chemotherapy regimes proposed individually for the patients [299-301]. An alternative programme is PREDICT + for the efficacy prediction based on individual HER2 parameters and hormone status [302-304].

Gene expression profiles receive more and more recognition in the overall breast cancer management

including typification, prediction, prognosis and therapy regiments. Based on the common gene expression patterns, the molecular breast cancer subtypes have been grouped into five classes, namely Luminal-A, Luminal-B, Basal-like, ErbB2-like and normal-like ones [305,306]. Therefrom, each intrinsic breast cancer subtype is characterised by an individual prognostic relevance, patterns of the metastatic disease and typical response to single therapy approaches [307-309]. Consequently, these intrinsic subtypes have been included into the St. Gallen Consensus Therapy Recommendations [293]. For the first time in the history of breast cancer management, the Consensus Expert Panel decides on the individualisation of the adjuvant therapy considering the molecular patterns as follows:
$>$ sole endocrine therapy in Luminal-A-cancers
$>$ endocrine therapy in combination with chemotherapy in Luminal-B cancers
$>$ sole chemotherapy in Basal-Like subtypes, and
$>$ chemotherapy in combination with anti-HER2 -treatment in ErbB2-like breast cancer.

Further, there are commercially available multi-gene assays that may be used to prognose individual recurrence scores and may assist in making decisions on single treatment regiments. The most common are MammaPrint and Oncotype DX assays [310,311]. Therewith, MammaPrint is able to distinguish breast cancer patients with a good prognosis to avoid unnecessary and even harmful treatments [312,313]. In contrast, the identified cohort of patients with a poor prognosis are more likely to achieve beneficial results by neo-adjuvant chemotherapy [314]. Oncotype $D X$ is developed for patients with hormone receptor positive tumours undergoing endocrine treatment with tamoxifen. Therefore, this test identifies patients with a low risk of the tumour recurrence, who would not benefit from additionally applied adjuvant chemotherapy [315]. An add-value of the Oncotype DX application as evident for the node-positive disease, since patients with high tumour-recurrence scores may well benefit from anthracycline-based chemotherapy [316]. Both assays are currently under the prospective study in the MINDACT trial (MammaPrint) and TAILORx trial (Oncotype DX) to validate their overall clinical utility for the personalised application of adjuvant chemotherapeutic approaches $[317,318]$.

\section{Recommendations and outlook}

Diagnosis and treatments of breast cancer metastasis disease (BCMD) are extremely challenging that prompts a development of emerging technologies for the effective prevention of breast cancer. Therefore, the overall task 
is formulated as the integrative medical approach of the multimodal diagnostics, disease specific biomarkerpatterns, individual patient profiles, creation of medical records and treatments tailored to the person. In this context, a minimally invasive breast cancer risk assessment appears to be a plausible approach for early / predictive diagnosis of cancer pre-stages and targeted treatments before the clinical onset of BCMD.

The multimodal diagnostiscs represents a model-based examination procedure with several levels of examination resulting in the extended patient profiles and medical records which should obligatory include an interview with the patient / a questionnaire form filled in for pathology relevant information, medical imaging, laboratory diagnostics and evaluation of pathology relevant risk factors. For the laboratory diagnostics it is highly recommended to use valid blood tests for the detection of the stage specific molecular patterns in activated leucocytes as explained above.

For the application of adjuvant therapeutic approaches, our ethical responsibility requests a carefully created balance between risks and benefits to justify the individually made decisions. A predictive genetic testing should be fixed by law to determine effective treatment options by evaluating efficacy, e.g. in the case of cytochrome P450 CYP2D6 genotyping to decide on tamoxifen application tailored to the patient.

Innovative medical records should be, further, developed to cover current deficits in the above listed clinical and laboratory expertise and to create individual patient profiles utilising mathematical modelling and integrative bioinformatics.

\section{Competing interests}

The authors declare that they have no competing interests.

\section{Authors' contributions}

OG created the concept of the project, made the data interpretation and drafted the article. KY carried out the molecular biological studies. VC participated in the creation of the concept of the article. DT supervised the patients recruitment and data collection at the Department of Radiology. MB supervised the patients recruitment and data collection at the Department of Obstetrics and Gynaecology. MD contributed to the drafting of the paper. WK supervised the project at the Department of Obstetrics and Gynaecology. HS supervised the project at the Department of Radiology. All authors read and approved the final manuscript.

\section{Acknowledgements}

Authors thank Dr. Michael Fountoulakis, Ms. Ageliki Papadopoulou and Mr. Kostas Vougas, Proteomics Research Unit and Biomedical Informatics Unit, Biomedical Research Foundation, Academy of Athens, Greece for their great contribution to the proteomics related expertise.

\section{Author details}

'Department of Radiology, Rheinische Friedrich-Wilhelms-University of Bonn, Sigmund-Freud-Str. 25, Bonn 53105, Germany. ${ }^{2}$ Breast Cancer Research Centre, University of Bonn, Bonn, Germany. ${ }^{3}$ European Medical Association, Brussels, Belgium. ${ }^{4}$ Department of Obstetrics and Gynaecology, University of Bonn, Bonn, Germany. ${ }^{5}$ Department of Gynaecology, Red Cross Clinics Munich, Munich, Germany.
Received: 15 November 2012 Accepted: 29 December 2012

Published: 19 February 2013

\section{References}

1. WHO: Cancer [http://www.who.int/mediacentre/factsheets/fs297/en/]

2. Jemal A, Siegel R, Ward E, Hao Y, Xu J, Thun MJ: Cancer Statistics, 2009. CA Cancer J Clin 2009, 59:225-249.

3. National Cancer Institute at the National Institutes of Health: Breast Cancer.; . http://www.cancer.gov/cancertopics/types/breast.

4. Lu J, Steeg PS, Price JE, Krishnamurthy S, Mani SA, Reuben J, Cristofanilli M, Dontu G, Bidaut L, Valero V, Hortobagyi GN, Yu D: Breast cancer metastasis: challenges and opportunities. Cancer Res 2009, 69:4951-4953.

5. Ross JS, Hortobagyi GN: Molecular Oncology of Breast Cancer. Ma: Jones \& Bartlett Pub; 2004.

6. Hayashi N, Yamauchi H: Role of circulating tumor cells and disseminated tumor cells in primary breast cancer. Breast Cancer 2012, 19:110-117.

7. Allard WJ, Matera J, Miller MC, Repollet M, Connelly MC, Rao C, Tibbe AGJ, Uhr JW, Terstappen LWMM: Tumor cells circulate in the peripheral blood of all major carcinomas but not in healthy subjects or patients with nonmalignant diseases. Clin Cancer Res 2004, 10:6897-6904.

8. Alix-Panabières $C$, Riethdorf $S$, Pantel $\mathrm{K}$ : Circulating tumor cells and bone marrow micrometastasis. Clin Cancer Res 2008, 14:5013-5021.

9. Ignatiadis M, Xenidis N, Perraki M, Apostolaki S, Politaki E, Kafousi M, Stathopoulos EN, Stathopoulou A, Lianidou E, Chlouverakis G, Sotiriou C, Georgoulias V, Mavroudis D: Different prognostic value of cytokeratin-19 mRNA positive circulating tumor cells according to estrogen receptor and HER2 status in early-stage breast cancer. J Clin Oncol 2007, 25:5194-5202.

10. Nguyen DX, Massagué J: Genetic determinants of cancer metastasis. Nat Rev Genet 2007, 8:341-352.

11. Braun M, Fountoulakis M, Yeghiazaryan K, Schild HH, Kuhn W, Golubnitschaja O: How realistic are non-invasive approaches in breast cancer prediction? In Predictive Diagnostics and Personalized Treatment: Dream or Reality. Edited by Golubnitschaja O. New York: Nova Science Publishers Inc; 2009:433-446.

12. Vorbach C, Capecchi MR, Penninger JM: Evolution of the mammary gland from the innate immune system? Bioessays 2006, 28:606-616.

13. Howard BA, Gusterson BA: Human breast development. J Mammary Gland Biol Neoplasia 2000, 5:119-137.

14. DeNardo DG, Coussens LM: Inflammation and breast cancer. Balancing immune response: crosstalk between adaptive and innate immune cells during breast cancer progression. Breast Cancer Res 2007, 9:212.

15. Dunn GP, Old LJ, Schreiber RD: The immunobiology of cancer immunosurveillance and immunoediting. Immunity 2004, 21:137-148.

16. Coronella-Wood JA, Hersh EM: Naturally occurring B-cell responses to breast cancer. Cancer Immunol Immunother 2003, 52:715-738.

17. Wong PY, Staren ED, Tereshkova N, Braun DP: Functional analysis of tumorinfiltrating leukocytes in breast cancer patients. J Surg Res 1998, 76:95-103.

18. Coussens LM, Werb Z: Inflammation and cancer. Nature 2002, 420:860-867.

19. Balkwill F, Charles KA, Mantovani A: Smoldering and polarized inflammation in the initiation and promotion of malignant disease. Cancer Cell 2005, 7:211-217.

20. Wiseman BS, Werb Z: Stromal effects on mammary gland development and breast cancer. Science 2002, 296:1046-1049.

21. Hojilla CV, Wood GA, Khokha R: Inflammation and breast cancer: metalloproteinases as common effectors of inflammation and extracellular matrix breakdown in breast cancer. Breast Cancer Res 2008, 10:205.

22. Golubnitschaja O, Costigliola V: Common origin but individual outcomes: time for new guidelines in personalized healthcare. Personalized Med 2010, 7:561-568.

23. Ross JS: Integrated diagnostics and personalized therapeutics in oncology. In Predictive Diagnostics and Personalized Treatment: Dream or Reality. Edited by Golubnitschaja O. New York: Nova Science Publishers Inc; 2009:399-431.

24. Yeghiazaryan K, Braun M, Mamlouk S, Schild HH, Golubnitschaja O: Are sideeffects of irradiation predictable for treatment of breast cancer patients? In Predictive Diagnostics and Personalized Treatment: Dream or Reality. New York: Nova Science Publishers Inc; 2009:447-456.

25. Gahan P: Circulating nucleic acids in plasma and serum: diagnosis and prognosis in cancer. EPMA J 2010, 1:503-512.

26. Mallmann M, Staratschek-Jox A, Rudlowski C, Braun M, Gaarz A, Wolfgarten M, Kuhn W, Schultze J: Prediction and prognosis: impact of gene 
expression profiling in personalized treatment of breast cancer patients. EPMA J 2010, 1:421-437.

27. Debald M, Wolfgarten M, Walgenbach-Brünagel G, Kuhn W, Braun M: Noninvasive proteomics - thinking about personalized breast cancer screening and treatment. EPMA J 2010, 1:413-420

28. Yeghiazaryan K, Mamlouk S, Trog D, Moenkemann H, Braun M, Kuhn W, Schild H, Golubnitschaja O: Irradiated breast cancer patients demonstrate subgroup-specific regularities in protein expression patterns of circulating leukocytes. Cancer Genomics Proteomics 2007, 4:411-418,

29. Golubnitschaja O: Cell cycle checkpoints: the role and evaluation for early diagnosis of senescence, cardiovascular, cancer, and neurodegenerative diseases. Amino Acids 2007, 32:359-371.

30. NIH / NCl: The Breast Cancer Risk Assessment Tool.; [http://www.cancer.gov/ bcrisktool/]

31. Cebioglu M, Schild HH, Golubnitschaja O: Diabetes mellitus as a risk factor for cancer: stress or viral etiology? Infect Disord Drug Targets 2008, 8:76-87.

32. Golubnitschaja O: Changing long-held beliefs is never easy: A Proposal for multimodal approaches in female healthcare - An Integrative view. In Healthcare Overview: New Perspectives. Edited by Costigliola V. Dordrecht Heidelberg New York London: Springer; 2012:251-268.

33. NIH / NCl: Sleep Disorders.; [http://www.cancer.gov/cancertopics/pdq/ supportivecare/sleepdisorders/HealthProfessional/page1/AllPages]

34. Richter K, Acker J, Kamcev N, Bajraktarov S, Piehl A, Niklewski G Recommendations for the prevention of breast cancer in shift workers. EPMA J 2011, 2:351-356.

35. Golubnitschaja O, Moenkemann H, Kim K, Mozaffari MS: DNA damage and expression of checkpoint genes p21(WAF1/CIP1) and 14-3-3 sigma in taurine-deficient cardiomyocytes. Biochem Pharmacol 2003, 66:511-517.

36. Yeghiazaryan K, Cebioglu M, Braun M, Kuhn W, Schild HH, Golubnitschaja O: Noninvasive subcellular imaging in breast cancer risk assessment: construction of diagnostic windows. Personalized Med 2011, 8:321-330.

37. Bechtel W, Bauer G: Catalase Protects Tumor Cells from Apoptosis Induction by Intercellular ROS Signaling. Anticancer Res 2009, 29:4541-4557.

38. Bai J, Cederbaum Al: Catalase Protects HepG2 Cells from Apoptosis Induced by DNA-damaging Agents by Accelerating the Degradation of p53. J Biol Chem 2003, 278:4660-4667.

39. Nishikawa M, Tamada A, Hyoudou K, Umeyama Y, Takahashi Y, Kobayashi Y, Kumai H, Ishida E, Staud F, Yabe Y, Takakura Y, Yamashita F, Hashida M: Inhibition of experimental hepatic metastasis by targeted delivery of catalase in mice. Clin Exp Metastasis 2004, 21:213-221.

40. Jang B-C, Paik J-H, Kim S-P, Shin D-H, Song D-K, Park J-G, Suh M-H, Park J-W, Suh S-I: Catalase induced expression of inflammatory mediators via activation of NF-kappaB, PI3K/AKT, p70S6K, and JNKs in BV2 microglia. Cell Signal 2005, 17:625-633.

41. Ahn J, Gammon MD, Santella RM, Gaudet MM, Britton JA, Teitelbaum SL, Terry MB, Nowell S, Davis W, Garza C, Neugut Al, Ambrosone CB: Associations between breast cancer risk and the catalase genotype, fruit and vegetable consumption, and supplement use. Am J Epidemiol 2005, 162:943-952.

42. Goh J, Enns L, Fatemie S, Hopkins H, Morton J, Pettan-Brewer C, Ladiges W: Mitochondrial targeted catalase suppresses invasive breast cancer in mice. BMC Cancer 2011, 11:191

43. Zou L, Jaramillo M, Whaley D, Wells A, Panchapakesa V, Das T, Roy P: Profilin-1 is a negative regulator of mammary carcinoma aggressiveness. Br J Cancer 2007, 97:1361-1371

44. Masui O, White NM, Desouza LV, Krakovska O, Matta A, Metias S, Khalil B, Romaschin AD, Honey RJ, Stewart R, Pace K, Bjarnason GA, Siu KW, Yousef GM: Quantitative proteomic analysis in metastatic renal cell carcinoma reveals a unique set of proteins with potential prognostic significance. Mol Cell Proteomics 2013, 12:132-144.

45. Roy $\mathrm{P}$, Jacobson $\mathrm{K}$ : Overexpression of profilin reduces the migration of invasive breast cancer cells. Cell Motil Cytoskeleton 2004, 57:84-95.

46. Wittenmayer N, Jandrig B, Rothkegel M, Schlüter K, Arnold W, Haensch W, Scherneck S, Jockusch BM: Tumor suppressor activity of profilin requires a functional actin binding site. Mol Biol Cell 2004, 15:1600-1608.

47. Cao Y, Motomura K, Ohtsuru A, Matsumoto T, Yamashita S, Kosaka M: Profilin gene expression and regulation in a temperature-sensitive breast cancer cell line: tsFT101. Pflugers Arch 1997, 434:341-345.

48. Janke J, Schlüter K, Jandrig B, Theile M, Kölble K, Arnold W, Grinstein E, Schwartz A, Estevéz-Schwarz L, Schlag PM, Jockusch BM, Scherneck S:
Suppression of tumorigenicity in breast cancer cells by the microfilament protein profilin 1. J Exp Med 2000, 191:1675-1686.

49. Rabinovitz I, Simpson K: The actin cytoskeleton and metastasis. In Cell Adhesion and Cytoskeletal Molecules in Metastasis. Edited by Cress AE, Nagle RB. Dordrecht: Springer; 2006:69-90

50. Renz M, Betz B, Niederacher D, Bender HG, Langowski J: Invasive breast cancer cells exhibit increased mobility of the actin-binding protein CapG. Int J Cancer 2008, 122:1476-1482.

51. Kim JY, Lee YG, Kim M-Y, Byeon SE, Rhee MH, Park J, Katz DR, Chain BM, Cho JY: Src-mediated regulation of inflammatory responses by actin polymerization. Biochem Pharmacol 2010, 79:431-443.

52. Pellegrin S, Mellor H: Actin stress fibres. J Cell Sci 2007, 120:3491-3499.

53. Sotiriou C, Pusztai L: Gene-expression signatures in breast cancer. N Engl J Med 2009, 360:790-800.

54. Dai E, Stewart M, Ritchie B, Mesaeli N, Raha S, Kolodziejczyk D, Hobman ML, Liu LY, Etches W, Nation N, Michalak M, Lucas A: Calreticulin, a Potential Vascular Regulatory Protein, Reduces Intimal Hyperplasia After Arterial Injury. Arterioscler Thromb Vasc Biol 1997, 17:2359-2368.

55. Watanabe K, Ohira H, Orikasa H, Saito K, Kanno K, Shioya Y, Obara K, Sato Y: Anti-calreticulin antibodies in patients with inflammatory bowel disease. Fukushima J Med Sci 2006, 52:1-11.

56. Alur M, Nguyen MM, Eggener SE, Jiang F, Dadras SS, Stern J, Kimm S, Roeh K, Kozlowski J, Pins M, Michalak M, Dhir R, Wang Z: Suppressive roles of calreticulin in prostate cancer growth and metastasis. Am J Pathol 2009, 175:882-890.

57. Kageyama S, Isono T, Iwaki H, Wakabayashi Y, Okada Y, Kontani K, Yoshimura K, Terai A, Arai Y, Yoshiki T: Identification by proteomic analysis of calreticulin as a marker for bladder cancer and evaluation of the diagnostic accuracy of its detection in urine. Clin Chem 2004, 50:857-866.

58. Lwin Z-M, Guo C, Salim A, Yip GW-C, Chew F-T, Nan J, Thike AA, Tan P-H, Bay B-H: Clinicopathological significance of calreticulin in breast invasive ductal carcinoma. Mod Pathol 2010, 23:1559-1566.

59. Liu H, Bowes RC, van de Water B, Sillence C, Nagelkerke JF, Stevens JL: Endoplasmic Reticulum Chaperones GRP78 and Calreticulin Prevent Oxidative Stress, Ca2+ Disturbances, and Cell Death in Renal Epithelial Cells. J Biol Chem 1997, 272:21751-21759.

60. Chahed K, Kabbage M, Ehret-Sabatier L, Lemaitre-Guillier C, Remadi S, Hoebeke J, Chouchane L: Expression of fibrinogen E-fragment and fibrin E-fragment is inhibited in the human infiltrating ductal carcinoma of the breast: the two-dimensional electrophoresis and MALDI-TOF-mass spectrometry analyses. Int J Oncol 2005, 27:1425-1431.

61. Quandt KS, Hultquist DE: Flavin reductase: sequence of CDNA from bovine liver and tissue distribution. Proc Natl Acad Sci U S A 1994, 91:9322-9326.

62. Lu H, Chen J, Planko L, Zigrino P, Klein-Hitpass L, Magin TM: Induction of inflammatory cytokines by a keratin mutation and their repression by a small molecule in a mouse model for EBS. J Invest Dermatol 2007, 127:2781-2789.

63. Lyda MH, Tetef $\mathrm{M}$, Carter NH, Ikle D, Weiss LM, Arber DA: Keratin immunohistochemistry detects clinically significant metastases in bone marrow biopsy specimens in women with lobular breast carcinoma. Am J Surg Pathol 2000, 24:1593-1599.

64. Hendrix MJC, Seftor EA, Chu Y-W, Trevor KT, Seftor REB: Role of intermediate filaments in migration, invasion and metastasis. Cancer Metastasis Rev 1996, 15:507-525.

65. Paccione RJ, Miyazaki H, Patel V, Waseem A, Gutkind JS, Zehner ZE, Yeudall WA: Keratin down-regulation in vimentin-positive cancer cells is reversible by vimentin RNA interference, which inhibits growth and motility. Mol Cancer Ther 2008, 7:2894-2903.

66. Russell D, Andrews PD, James J, Lane EB: Mechanical stress induces profound remodelling of keratin filaments and cell junctions in epidermolysis bullosa simplex keratinocytes. J Cell Sci 2004, 117:5233-5243.

67. Sivaramakrishnan S, Schneider JL, Sitikov A, Goldman RD, Ridge KM: Shear Stress Induced Reorganization of the Keratin Intermediate Filament Network Requires Phosphorylation by Protein Kinase C $\zeta$. Mol Biol Cell 2009, 20:2755-2765.

68. Tung JJ, Kitajewski J: Chloride intracellular channel 1 functions in endothelial cell growth and migration. J Angiogenes Res 2010, 2:23.

69. Wang J-W, Peng S-Y, Li J-T, Wang Y, Zhang Z-P, Cheng Y, Cheng D-Q, Weng W-H, Wu X-S, Fei X-Z, Quan Z-W, Li J-Y, Li S-G, Liu Y-B: Identification of 
metastasis-associated proteins involved in gallbladder carcinoma metastasis by proteomic analysis and functional exploration of chloride intracellular channel 1. Cancer Lett 2009, 281:71-81.

70. Suginta W, Karoulias N, Aitken A, Ashley RH: Chloride intracellular channel protein CLIC4 (p64H1) binds directly to brain dynamin I in a complex containing actin, tubulin and 14-3-3 isoforms. Biochem J 2001, 359:55-64

71. Suh KS, Mutoh M, Nagashima K, Fernandez-Salas E, Edwards LE, Hayes DD, Crutchley JM, Marin KG, Dumont RA, Levy JM, Cheng C, Garfield S, Yuspa $\mathrm{SH}$ : The organellular chloride channel protein CLIC4/mtCLIC translocates to the nucleus in response to cellular stress and accelerates apoptosis. J Biol Chem 2004, 279:4632-4641.

72. Beliakoff J, Whitesell L: Hsp90: an emerging target for breast cancer therapy. Anticancer Drugs 2004, 15:651-662.

73. Yaobin, Tong W, Zhu Y: Study on HSP70, 90 mRNA gene expression in peripheral blood mononuclear cells with steroid-resistant asthmatics. Zhonghua Jie He He Hu Xi Za Zhi 1998, 21:289-292.

74. Njemini R, Bautmans I, Onyema O, Puyvelde KV, Demanet C, Mets T: Circulating Heat Shock Protein 70 in Health, Aging and Disease. BMC Immunol 2011, 12:24

75. Ciocca DR, Calderwood SK: Heat shock proteins in cancer: diagnostic, prognostic, predictive, and treatment implications. Cell Stress Chaperones 2005, 10:86-103.

76. Zhang M-H, Lee J-S, Kim H-J, Jin D-I, Kim J-I, Lee K-J, Seo J-S: HSP90 protects apoptotic cleavage of vimentin in geldanamycin-induced apoptosis. Mol Cell Biochem 2006, 281:111-121.

77. Liu J, Chen J, Yu L, Tian Y, Cui X, Yan Q, Fu L: Inhibitory effect of ginsenoside-Rg3 on lung metastasis of mouse melanoma transfected with ribonuclease inhibitor. Zhonghua Zhong Liu Za Zhi 2004, 26:722-725.

78. Chen J, Ou-Yang X, Gao J, Zhu J, He X, Rong J: Knockdown of ribonuclease inhibitor expression with siRNA in non-invasive bladder cancer cell line BIU-87 promotes growth and metastasis potentials. Mol Cell Biochem 2010, 349:83-95.

79. Dickson KA: Effect of the Ribonuclease Inhibitor on the Biological Activity of Pancreatic-Type Ribonucleases. PhD thesis. Madison: University of Wisconsin; 2006.

80. Moenner M, Vosoghi M, Ryazantsev S, Glitz DG: Ribonuclease inhibitor protein of human erythrocytes: characterization, loss of activity in response to oxidative stress, and association with Heinz bodies. Blood Cells Mol Dis 1998, 24:149-164.

81. Fominaya JM, Hofsteenge J: Inactivation of ribonuclease inhibitor by thioldisulfide exchange. J Biol Chem 1992, 267:24655-24660.

82. Chen J-X, Gao Y, Liu J-W, Tian Y-X, Zhao J, Cui X-Y: Antitumor effects of human ribonuclease inhibitor gene transfected on B16 melanoma cells. Int J Biochem Cell Biol 2005, 37:1219-1231.

83. Tumor Research Center: The Influences of Human Placental Ribonuclease Inhibitor Mutants on Their Biological Activities.; [http://www.tumorres.com/ brain-tumor/10397.htm]

84. Wulf G, Garg P, Liou Y-C, Iglehart D, Lu KP: Modeling breast cancer in vivo and ex vivo reveals an essential role of Pin 1 in tumorigenesis. EMBO J 2004, 23:3397-3407.

85. Bao L, Kimzey A, Sauter G, Sowadski JM, Lu KP, Wang D-G: Prevalent overexpression of prolyl isomerase Pin1 in human cancers. Am J Pathol 2004, 164:1727-1737

86. Song F, Zhang X, Ren X-B, Zhu P, Xu J, Wang L, Li Y-F, Zhong N, Ru Q, Zhang D-W, Jiang J-L, Xia B, Chen Z-N: Cyclophilin A (CyPA) induces chemotaxis independent of its peptidylprolyl cis-trans isomerase activity: direct binding between CyPA and the ectodomain of CD147. J Biol Chem 2011, 286:8197-8203.

87. Dourlen P, Ando K, Hamdane M, Begard S, Buée L, Galas MC: The peptidyl prolyl cis/trans isomerase Pin1 downregulates the Inhibitor of Apoptosis Protein Survivin. Biochim Biophys Acta 2007, 1773:1428-1437.

88. Yue F, Wang L-S, Xia L, Wang X-L, Feng B, Lu A-G, Chen G-Q, Zheng M-H: Modulated T-complex protein $1 \zeta$ and peptidyl-prolyl cis-trans isomerase $B$ are two novel indicators for evaluating lymph node metastasis in colorectal cancer: Evidence from proteomics and bioinformatics. Proteomics Clin Appl 2009, 3:1225-1235.

89. Wulf GM, Ryo A, Wulf GG, Lee SW, Niu T, Petkova V, Lu KP: Pin1 is overexpressed in breast cancer and cooperates with Ras signaling in increasing the transcriptional activity of c-Jun towards cyclin D1. EMBO J 2001, 20:3459-3472.
90. Thaiparambil J, Bender L, Kline E, Ganesh T, Snyder J, Liotta D, Marcus A: Vimentin: A Novel Chemopreventive Target for Breast Cancer Metastasis. Cancer Res 2010, 69:5063-5063.

91. Kokkinos MI, Wafai R, Wong MK, Newgreen DF, Thompson EW, Waltham M: Vimentin and epithelial-mesenchymal transition in human breast cancer-observations in vitro and in vivo. Cells Tissues Organs (Print) 2007, 185:191-203.

92. Kusinska RU, Kordek R, Pluciennik E, Bednarek AK, Piekarski JH, Potemski P. Does vimentin help to delineate the so-called "basal type breast cancer"? J Exp Clin Cancer Res 2009, 28:118.

93. Vuoriluoto K, Haugen H, Kiviluoto S, Mpindi J-P, Nevo J, Gjerdrum C, Tiron C, Lorens JB, Ivaska J: Vimentin regulates EMT induction by Slug and oncogenic $\mathrm{H}$-Ras and migration by governing $\mathrm{Axl}$ expression in breast cancer. Oncogene 2011, 30:1436-1448.

94. Korsching E, Packeisen J, Liedtke C, Hungermann D, Wülfing P, van Diest PJ, Brandt $B$, Boecker $W$, Buerger $H$ : The origin of vimentin expression in invasive breast cancer: epithelial-mesenchymal transition, myoepithelial histogenesis or histogenesis from progenitor cells with bilinear differentiation potential? J Pathol 2005, 206:451-457.

95. Moisan E, Chiasson S, Girard D: The intriguing normal acute inflammatory response in mice lacking vimentin. Clin Exp Immunol 2007, 150:158-168.

96. Mor-Vaknin N, Punturieri A, Sitwala K, Markovitz DM: Vimentin is secreted by activated macrophages. Nat Cell Biol 2002, 5:59-63.

97. Wei J, Xu G, Wu M, Zhang Y, Li Q, Liu P, Zhu T, Song A, Zhao L, Han Z, Chen G, Wang S, Meng L, Zhou J, Lu Y, Wang S, Ma D: Overexpression of vimentin contributes to prostate cancer invasion and metastasis via src regulation. Anticancer Res 2008, 28:327-334.

98. Tafreshi NK, Bui MM, Bishop K, Lloyd MC, Enkemann SA, Lopez AS, Abrahams D, Carter BW, Vagner J, Grobmyer SR, Gobmyer SR, Gillies RJ, Morse DL: Noninvasive detection of breast cancer lymph node metastasis using carbonic anhydrases IX and XII targeted imaging probes. Clin Cancer Res 2012, 18:207-219.

99. Pastorekova S, Zatovicova M, Pastorek J: Cancer-associated carbonic anhydrases and their inhibition. Curr Pharm Des 2008, 14:685-698.

100. Bekku S, Mochizuki H, Yamamoto T, Ueno H, Takayama E, Tadakuma T: Expression of carbonic anhydrase I or II and correlation to clinical aspects of colorectal cancer. Hepatogastroenterology 2000, 47:998-1001.

101. Knudsen JF, Carlsson U, Hammarström P, Sokol GH, Cantilena LR: The Cyclooxygenase-2 Inhibitor Celecoxib Is a Potent Inhibitor of Human Carbonic Anhydrase II. Inflammation 2004, 28:285-290.

102. Radhakrishnan R, Sluka KA: Acetazolamide, a carbonic anhydrase inhibitor, reverses inflammation-induced thermal hyperalgesia in rats. J Pharmacol Exp Ther 2005, 313:921-927.

103. Yasukawa Z, Sato C, Kitajima K: Identification of an inflammation-inducible serum protein recognized by anti-disialic acid antibodies as carbonic anhydrase II. J Biochem 2007, 141:429-441.

104. Bodh S, Kumar V, Raina U, Ghosh B, Thakar M: Inflammatory glaucoma. Oman J Ophthalmol 2011, 4:3.

105. Martínez JM, Prieto I, Ramírez MJ, Cueva C, Alba F, Ramírez M: Aminopeptidase Activities in Breast Cancer Tissue. Clin Chem 1999, 45:1797-1802

106. Sekine K, Fujii H, Abe F, Nishikawa K: Augmentation of death ligandinduced apoptosis by aminopeptidase inhibitors in human solid tumor cell lines. Int J Cancer 2001, 94:485-491.

107. Varona A, Blanco L, López Jl, Gil J, Agirregoitia E, Irazusta J, Larrinaga G: Altered levels of acid, basic, and neutral peptidase activity and expression in human clear cell renal cell carcinoma. Am J Physiol Renal Physiol 2007, 292:F780-F788.

108. Bukowska A, Tadje J, Arndt M, Wolke C, Kähne T, Bartsch J, Faust J, Neubert K, Hashimoto Y, Lendeckel U: Transcriptional regulation of cytosol and membrane alanyl-aminopeptidase in human T cell subsets. Biol Chem 2003, 384:657-665.

109. Röhnert P, Schmidt W, Emmerlich P, Goihl A, Wrenger S, Bank U, Nordhoff K, Täger M, Ansorge S, Reinhold D, Striggow F: Dipeptidyl peptidase IV, aminopeptidase $\mathrm{N}$ and DPIV/APN-like proteases in cerebral ischemia. J Neuroinflammation 2012, 9:44.

110. Xu C, Wang J, Li J, Fang R: Expression of Elongation Factor (EF)-Tu Is Correlated with Prognosis of Gastric Adenocarcinomas. Int J Mol Sci 2011, 12:6645-6655.

111. Zheng G, Peng F, Ding R, Yu Y, Ouyang Y, Chen Z, Xiao Z, He Z: Identification of proteins responsible for the multiple drug resistance in 
5-fluorouracil-induced breast cancer cell using proteomics analysis. J Cancer Res Clin Oncol 2010, 136:1477-1488.

112. Fritz G, Just I, Kaina B: Rho GTPases are over-expressed in human tumors. Int J Cancer 1999, 81:682-687.

113. Seraj MJ, Harding MA, Gildea JJ, Welch DR, Theodorescu D: The relationship of BRMS1 and RhoGDI2 gene expression to metastatic potential in lineage related human bladder cancer cell lines. Clin Exp Metastasis 2000, 18:519-525.

114. Fujita A, Shida A, Fujioka S, Kurihara H, Okamoto T, Yanaga K: Clinical significance of Rho GDP dissociation inhibitor 2 in colorectal carcinoma. Int J Clin Oncol 2012, 17:137-142.

115. Moissoglu K, McRoberts KS, Meier JA, Theodorescu D, Schwartz MA: Rho GDP dissociation inhibitor 2 suppresses metastasis via unconventional regulation of RhoGTPases. Cancer Res 2009, 69:2838-2844.

116. Zhang B, Zhang Y, Dagher M-C, Shacter E: Rho GDP Dissociation Inhibitor Protects Cancer Cells against Drug-Induced Apoptosis. Cancer Res 2005, 65:6054-6062

117. Vercoutter-Edouart AS, Lemoine J, Le Bourhis X, Louis H, Boilly B, Nurcombe $V$, Révillion F, Peyrat JP, Hondermarck H: Proteomic analysis reveals that 14-3-3sigma is down-regulated in human breast cancer cells. Cancer Res 2001, 61:76-80.

118. Pan Y, Zhong L, Zhou H, Wang X, Chen K, Yang H, Xiaokaiti Y, Maimaiti A, Jiang L, Li X: Roles of vimentin and 14-3-3 zeta/delta in the inhibitory effects of heparin on PC-3M cell proliferation and B16-F10-luc-G5 cells metastasis. Acta Pharmacol Sin 2012, 33:798-808.

119. Wong TT, Zhou L, Li J, Tong L, Zhao SZ, Li XR, Yu SJ, Koh SK, Beuerman RW: Proteomic profiling of inflammatory signaling molecules in the tears of patients on chronic glaucoma medication. Invest Ophthalmol Vis Sci 2011, 52:7385-7391.

120. Croce K, Gao H, Wang Y, Mooroka T, Sakuma M, Shi C, Sukhova GK, Packard RRS, Hogg N, Libby P, Simon Dl: Myeloid-related protein-8 $/ 14$ is critical for the biological response to vascular injury. Circulation 2009, 120:427-436.

121. Leach ST, Mitchell HM, Geczy CL, Sherman PM, Day AS: S100 calgranulin proteins S100A8, S100A9 and S100A12 are expressed in the inflamed gastric mucosa of Helicobacter pylori-infected children. Can J Gastroenterol 2008, 22:461-464.

122. Carlsson H, Petersson S, Enerbäck C: Cluster analysis of S100 gene expression and genes correlating to psoriasin (S100A7) expression at different stages of breast cancer development. Int J Oncol 2005, 27:1473-1481.

123. Kennedy RD, Gorski JJ, Quinn JE, Stewart GE, James CR, Moore S, Mulligan K, Emberley ED, Lioe TF, Morrison PJ, Mullan PB, Reid G, Johnston PG, Watson $\mathrm{PH}$, Harkin DP: BRCA1 and c-Myc associate to transcriptionally repress psoriasin, a DNA damage-inducible gene. Cancer Res 2005, 65:10265-10272.

124. Rust R, Visser L, van der Leij J, Harms G, Blokzij T, Deloulme JC, van der Vlies P, Kamps W, Kok K, Lim M, Poppema S, van den Berg A: High expression of calcium-binding proteins, S100A10, S100A11 and CALM2 in anaplastic large cell lymphoma. Br J Haematol 2005, 131:596-608.

125. Cross SS, Hamdy FC, Deloulme JC, Rehman I: Expression of S100 proteins in normal human tissues and common cancers using tissue microarrays: S100A6, S100A8, S100A9 and S100A11 are all overexpressed in common cancers. Histopathology 2005, 46:256-269.

126. Hermani A, Hess J, Servi BD, Medunjanin S, Grobholz R, Trojan L, Angel P, Mayer D: Calcium-Binding Proteins S100A8 and S100A9 as Novel Diagnostic Markers in Human Prostate Cancer. Clin Cancer Res 2005, 11:5146-5152.

127. Bode G, Lüken A, Kerkhoff C, Roth J, Ludwig S, Nacken W: Interaction between S100A8/A9 and annexin A6 is involved in the calciuminduced cell surface exposition of S100A8/A9. J Biol Chem 2008, 283:31776-31784

128. Lee H-H, Lim C-A, Cheong Y-T, Singh M, Gam L-H: Comparison of protein expression profiles of different stages of lymph nodes metastasis in breast cancer. Int J Biol Sci 2012, 8:353-362.

129. Rao KVK, Boukli NM, Samikkannu T, Cubano LA, Dakshayani BK, Nair MP: Proteomics Profiling and Cytotoxic Effect of Curcuma longa on Prostate Cancer. Open Proteomics J 2011, 4:1-11.

130. Goplen D, Wang J, Enger PØ, Tysnes BB, Terzis AJA, Laerum OD, Bjerkvig R: Protein Disulfide Isomerase Expression Is Related to the Invasive Properties of Malignant Glioma. Cancer Res 2006, 66:9895-9902.
131. Hoffstrom BG, Kaplan A, Letso R, Schmid RS, Turmel GJ, Lo DC, Stockwell BR: Inhibitors of protein disulfide isomerase suppress apoptosis induced by misfolded proteins. Nat Chem Biol 2010, 6:900-906.

132. Satish L, Johnson S, Wang JH-C, Post JC, Ehrlich GD, Kathju S: Chaperonin Containing T-Complex Polypeptide Subunit Eta (CCT-eta) Is a Specific Regulator of Fibroblast Motility and Contractility. PLoS One 2010, 5:e10063.

133. Wong STC, Zhao H: Molecular Diagnostic Methods for Predicting Brain Metastasis of Breast Cancer; International Patent US 2012/0184560 A1.

134. Poulsen N, Andersen V, Møller J, Møller H, Jessen F, Purup S, Larsen L: Comparative analysis of inflamed and non-inflamed colon biopsies reveals strong proteomic inflammation profile in patients with ulcerative colitis. BMC Gastroenterol 2012, 12:76.

135. Tamesa MS, Kuramitsu Y, Fujimoto M, Maeda N, Nagashima Y, Tanaka T, Yamamoto S, Oka M, Nakamura K: Detection of autoantibodies against cyclophilin A and triosephosphate isomerase in sera from breast cancer patients by proteomic analysis. Electrophoresis 2009, 30:2168-2181.

136. Dang Y, Wang Z, Guo Y, Yang J, Xing Z, Mu L, Zhang X, Ding Z: Overexpression of triosephosphate isomerase inhibits proliferation of chicken embryonal fibroblast cells. Asian Pac J Cancer Prev 2011, 12:3479-3482.

137. Zhang X, Xiao Z, Li C, Xiao Z, Yang F, Li D, Li M, Li F, Chen Z: Triosephosphate isomerase and peroxiredoxin 6, two novel serum markers for human lung squamous cell carcinoma. Cancer Sci 2009, 100:2396-2401.

138. Ang EZ-F, Nguyen HT, Sim H-L, Putti TC, Lim LHK: Annexin-1 Regulates Growth Arrest Induced by High Levels of Estrogen in MCF-7 Breast Cancer Cells. Mol Cancer Res 2009, 7:266-274.

139. Nair S, Hande MP, Lim LHK: Annexin-1 protects MCF7 breast cancer cells against heat-induced growth arrest and DNA damage. Cancer Lett 2010, 294:111-117.

140. Zhang Z, Huang L, Zhao W, Rigas B: Annexin 1 induced by antiinflammatory drugs binds to NF-KB inhibiting its activation: Anticancer effects in vitro and in vivo. Cancer Res 2010, 70:2379-2388.

141. Peers SH, Smillie F, Elderfield AJ, Flower RJ: Glucocorticoid-and nonglucocorticoid induction of lipocortins (annexins) 1 and 2 in rat peritoneal leucocytes in vivo. Br J Pharmacol 1993, 108:66-72.

142. Mojtahedi Z, Erfani N, Ghaderi A: Comparative Proteomics Analysis of SKBR3 and MCF7 Breast Cancer Cell Lines Using Two Dimensional Electrophoresis: Ready to Build Postgenomics Capacity for OMICS R\&D in Developing Countries? Curr Pharmacogenomics Personalized Med 2012, 10:132-137.

143. Májek P, Reicheltová Z, Stikarová J, Suttnar J, Sobotková A, Dyr JE: Proteome changes in platelets activated by arachidonic acid, collagen, and thrombin. Proteome Sci 2010, 8:56.

144. España L, Martín B, Aragüés $R$, Chiva C, Oliva B, Andreu D, Sierra A: Bcl-x(L)mediated changes in metabolic pathways of breast cancer cells: from survival in the blood stream to organ-specific metastasis. Am J Pathol 2005, 167:1125-1137.

145. Wang C-Y, Chen J-K, Wu Y-T, Tsai M-J, Shyue S-K, Yang C-S, Tzeng S-F: Reduction in antioxidant enzyme expression and sustained inflammation enhance tissue damage in the subacute phase of spinal cord contusive injury. J Biomed Sci 2011, 18:13.

146. Karihtala P, Mäntyniemi A, Kang SW, Kinnula VL, Soini Y: Peroxiredoxins in Breast Carcinoma. Clin Cancer Res 2003, 9:3418-3424.

147. Chang X-Z, Li D-Q, Hou Y-F, Wu J, Lu J-S, Di G-H, Jin W, Ou Z-L, Shen Z-Z, Shao Z-M: Identification of the functional role of peroxiredoxin 6 in the progression of breast cancer. Breast Cancer Res 2007, 9:R76.

148. Ho J-N, Lee SB, Lee S-S, Yoon SH, Kang GY, Hwang S-G, Um H-D: Phospholipase A2 Activity of Peroxiredoxin 6 Promotes Invasion and Metastasis of Lung Cancer Cells. Mol Cancer Ther 2010, 9:825-832.

149. Wang Y, Phelan SA, Manevich Y, Feinstein SI, Fisher AB: Transgenic Mice Overexpressing Peroxiredoxin 6 Show Increased Resistance to Lung Injury in Hyperoxia. Am J Respir Cell Mol Biol 2006, 34:481-486.

150. Sundar IK, Chung S, Hwang J-W, Arunachalam G, Cook S, Yao H, Mazur W, Kinnula VL, Fisher $A B$, Rahman I: Peroxiredoxin 6 differentially regulates acute and chronic cigarette smoke-mediated lung inflammatory response and injury. Exp Lung Res 2010, 36:451-462.

151. Somiari RI, Somiari S, Russell S, Shriver CD: Proteomics of breast carcinoma. J Chromatogr B Analyt Technol Biomed Life Sci 2005, 815:215-225. 
152. Lee J, Namkoong $H$, Kim H, Kim S, Hwang D, Na H, Ha S-A, Kim J-R, Kim J: Fibrinogen gamma-A chain precursor in CSF: a candidate biomarker for Alzheimer's disease. BMC Neurol 2007, 7:14

153. Akakura N, Hoogland C, Takada YK, Saegusa J, Ye X, Liu F-T, Cheung AT-W, Takada $Y$ : The $\mathrm{COOH}$-terminal globular domain of fibrinogen gamma chain suppresses angiogenesis and tumor growth. Cancer Res 2006 66:9691-9697.

154. Palumbo JS, Kombrinck KW, Drew AF, Grimes TS, Kiser JH, Degen JL, Bugge $\mathrm{TH}$ : Fibrinogen is an important determinant of the metastatic potential of circulating tumor cells. Blood 2000, 96:3302-3309.

155. Lu C, Mishra A, Zhu YJ, Meltzer P, Cheng S-Y: Genomic profiling of genes contributing to metastasis in a mouse model of thyroid follicular carcinoma. Am J Cancer Res 2011, 1:1-13.

156. Zhu W-L, Fan B-L, Liu D-L, Zhu W-X: Abnormal Expression of Fibrinogen Gamma (FGG) and Plasma Level of Fibrinogen in Patients with Hepatocellular Carcinoma. Anticancer Res 2009, 29:2531-2534.

157. Du J, Zheng J-H, Chen X-S, Yang Q, Zhang Y-H, Zhou L, Yao X: High preoperative plasma fibrinogen is an independent predictor of distant metastasis and poor prognosis in renal cell carcinoma. Int J Clin Oncol 2012. doi:10.1007/s10147-012-0412-x.

158. Domeika M, Domeika K, Paavonen J, Mårdh PA, Witkin SS: Humoral immune response to conserved epitopes of Chlamydia trachomatis and human 60-kDa heat-shock protein in women with pelvic inflammatory disease. J Infect Dis 1998, 177:714-719.

159. Lohse AW, Dienes HP, Herkel J, Hermann E, van Eden W, Büschenfelde KHM: Expression of the $60 \mathrm{kDa}$ heat shock protein in normal and inflamed liver. J Hepatol 1993, 19:159-166.

160. Chen W, Syldath U, Bellmann K, Burkart V, Kolb H: Human 60-kDa heatshock protein: a danger signal to the innate immune system. J Immunol 1999, 162:3212-3219.

161. Pockley AG: Heat Shock Proteins, Inflammation, and Cardiovascular Disease. Circulation 2002, 105:1012-1017.

162. Grundtman C, Kreutmayer SB, Almanzar G, Wick MC, Wick G: Heat Shock Protein 60 and Immune Inflammatory Responses in Atherosclerosis. Arterioscler Thromb Vasc Biol 2011, 31:960-968.

163. Kligman I, Grifo JA, Witkin SS: Expression of the $60 \mathrm{kDa}$ heat shock protein in peritoneal fluids from women with endometriosis: implications for endometriosis-associated infertility. Hum Reprod 1996, 11:2736-2738.

164. Hwang YJ, Lee SP, Kim SY, Choi YH, Kim MJ, Lee CH, Lee JY, Kim DY: Expression of Heat Shock Protein $60 \mathrm{kDa}$ Is Upregulated in Cervical Cancer. Yonsei Med J 2009, 50:399-406.

165. Barazi HO, Zhou L, Templeton NS, Krutzsch HC, Roberts DD: Identification of Heat Shock Protein 60 as a Molecular Mediator of a3 $\beta 1$ Integrin Activation. Cancer Res 2002, 62:1541-1548.

166. Cappello F, Bellafiore M, Palma A, David S, Marcianò V, Bartolotta T, Sciumè C, Modica G, Farina F, Zummo G, Bucchieri F: 60KDa chaperonin (HSP60) is overexpressed during colorectal carcinogenesis. Eur J Histochem 2003, 47:105-110.

167. Shrinivasan A, Poongothai A, Rao C, Srinivasulu M, Vishnupriya S: Serum Lactate Dehydrogenase (LDH) Levels In Breast Cancer. Indian J Hum Genet 1999, 5:21.

168. Olinga P, Merema MT, de Jager MH, Derks F, Melgert BN, Moshage H, Slooff MJ, Meijer DK, Poelstra K, Groothuis GM: Rat liver slices as a tool to study LPSinduced inflammatory response in the liver. J Hepatol 2001, 35:187-194.

169. Chen Y, Zhang H, Xu A, Li N, Liu J, Liu C, Lv D, Wu S, Huang L, Yang S, He $D$, Xiao X: Elevation of serum I-lactate dehydrogenase B correlated with the clinical stage of lung cancer. Lung Cancer 2006, 54:95-102.

170. Hussien R, Brooks GA: Mitochondrial and plasma membrane lactate transporter and lactate dehydrogenase isoform expression in breast cancer cell lines. Physio/ Genomics 2011, 43:255-264.

171. Singh TD, Barbhuiya MA, Gupta S, Shrivastav BR, Jalaj V, Agarwal N, Tiwari PK: Quantitative Assessment of Expression of Lactate Dehydrogenase and its Isoforms 3 and 4 may Serve as Useful Indicators of Progression of Gallbladder Cancer: A Pilot Study. Indian J Clin Biochem 2011, 26:146-153.

172. Chen Y, Zhang H, Xu A, Liu J, Li N, Wu S, Huang L, He D, Xiao X: Identification and clinical evaluation of lung cancer serum biomarker L-lactate dehydrogenase B. Zhonghua Jie He He Hu Xi Za Zhi 2007, 30:577-581.

173. Gay O, Gilquin B, Pitaval A, Baudier J: Refilins: A link between perinuclear actin bundle dynamics and mechanosensing signaling. BioArchitecture 2011, 1:245-249.
174. Le TH: Protein dynamics in responder and non-responder solid tumor xenografts during oncolytic viral therapy. PhD thesis.: Bayerische JuliusMaximilians-Universität zu Würzburg; 2008.

175. Yu N: The role of the P2Y2 nucleotide receptors in vascular inflammation. PhD thesis.: University of Missouri; 2007.

176. Zhong Z, Yeow W-S, Zou C, Wassell R, Wang C, Pestell RG, Quong JN, Quong AA: Cyclin D1/Cyclin-Dependent Kinase 4 Interacts with Filamin A and Affects the Migration and Invasion Potential of Breast Cancer Cells. Cancer Res 2010, 70:2105-2114.

177. Xu Y, Bismar TA, Su J, Xu B, Kristiansen G, Varga Z, Teng L, Ingber DE, Mammoto A, Kumar R, Alaoui-Jamali MA: Filamin A regulates focal adhesion disassembly and suppresses breast cancer cell migration and invasion. J Exp Med 2010, 207:2421-2437.

178. Stevenson RP, Veltman D, Machesky LM: Actin-bundling proteins in cancer progression at a glance. J Cell Sci 2012, 125:1073-1079.

179. Gasparini G, Toi M, Biganzoli E, Dittadi R, Fanelli M, Morabito A, Boracchi P, Gion M: Thrombospondin-1 and -2 in Node-Negative Breast Cancer: Correlation with Angiogenic Factors, p53, Cathepsin D, Hormone Receptors and Prognosis. Oncology 2001, 60:72-80.

180. Hyder SM, Liang Y, Wu J: Estrogen regulation of thrombospondin-1 in human breast cancer cells. Int J Cancer 2009, 125:1045-1053.

181. Sargiannidou I, Zhou J, Tuszynski GP: The Role of Thrombospondin-1 in Tumor Progression. Exp Biol Med (Maywood) 2001, 226:726-733.

182. Yee KO, Connolly CM, Duquette M, Kazerounian S, Washington R, Lawler J: The effect of thrombospondin-1 on breast cancer metastasis. Breast Cancer Res Treat 2009, 114:85-96.

183. Lopez-Dee Z, Pidcock K, Gutierrez LS: Thrombospondin-1: Multiple Paths to Inflammation. Mediators Inflamm 2011, 2011:1-10

184. Rice AJ, Steward MA, Quinn CM: Thrombospondin 1 protein expression relates to good prognostic indices in ductal carcinoma in situ of the breast. J Clin Pathol 2002, 55:921-925.

185. Alaoui-Jamali MA, Song DJ, Benlimame N, Yen L, Deng X, Hernandez-Perez $M$, Wang $T$ : Regulation of multiple tumor microenvironment markers by overexpression of single or paired combinations of ErbB receptors. Cancer Res 2003, 63:3764-3774

186. Wang-Rodriguez J, Urquidi V, Rivard A, Goodison S: Elevated osteopontin and thrombospondin expression identifies malignant human breast carcinoma but is not indicative of metastatic status. Breast Cancer Res 2003, 5:R136-R143

187. Fontana A, Filleur S, Guglielmi J, Frappart L, Bruno-Bossio G, Boissier S, Cabon F, Clézardin P: Human breast tumors override the antiangiogenic effect of stromal thrombospondin-1 in vivo. Int J Cancer 2005, 116:686-691.

188. Manni A, Washington S, Mauger D, Hackett DA, Verderame MF: Cellular mechanisms mediating the anti-invasive properties of the ornithine decarboxylase inhibitor alpha-difluoromethylornithine (DFMO) in human breast cancer cells. Clin Exp Metastasis 2004, 21:461-467.

189. Suh EJ, Kabir MH, Kang U-B, Lee JW, Yu J, Noh D-Y, Lee C: Comparative profiling of plasma proteome from breast cancer patients reveals thrombospondin-1 and BRWD3 as serological biomarkers. Exp Mol Med 2012, 44:36-44.

190. Leppilampi M, Koistinen P, Savolainen E-R, Hannuksela J, Parkkila A-K, Niemelä O, Pastoreková S, Pastorek J, Waheed A, Sly WS, Parkkila S, Rajaniemi $\mathrm{H}$ : The expression of carbonic anhydrase II in hematological malignancies. Clin Cancer Res 2002, 8:2240-2245.

191. Parkkila S, Rajaniemi H, Parkkila AK, Kivela J, Waheed A, Pastorekova S, Pastorek J, Sly WS: Carbonic anhydrase inhibitor suppresses invasion of renal cancer cells in vitro. Proc Natl Acad Sci U S A 2000, 97:2220-2224.

192. Spiegelman VS, Tang W, Chan AM, Igarashi M, Aaronson SA, Sassoon DA, Katoh M, Slaga TJ, Fuchs SY: Induction of homologue of Slimb ubiquitin ligase receptor by mitogen signaling. J Biol Chem 2002, 277:36624-36630

193. Tran M, Tam D, Bardia A, Bhasin M, Rowe GC, Kher A, Zsengeller ZK, Akhavan-Sharif MR, Khankin EV, Saintgeniez M, David S, Burstein D, Karumanchi SA, Stillman IE, Arany Z, Parikh SM: PGC-1 a promotes recovery after acute kidney injury during systemic inflammation in mice. J Clin Invest 2011, 121:4003-4014.

194. Gao B-B, Phipps JA, Bursell D, Clermont AC, Feener EP: Angiotensin AT1 receptor antagonism ameliorates murine retinal proteome changes induced by diabetes. J Proteome Res 2009, 8:5541-5549.

195. Putignani L, Raffa S, Pescosolido R, Rizza T, Del Chierico F, Leone L, Aimati L, Signore F, Carrozzo R, Callea F, Torrisi MR, Grammatico P: Preliminary 
evidences on mitochondrial injury and impaired oxidative metabolism in breast cancer. Mitochondrion 2012, 12:363-369.

196. Suhane S, Berel D, Ramanujan VK: Biomarker signatures of mitochondrial NDUFS3 in invasive breast carcinoma. Biochem Biophys Res Commun 2011, 412:590-595.

197. Kulawiec M, Owens KM, Singh KK: mtDNA G10398A variant in AfricanAmerican women with breast cancer provides resistance to apoptosis and promotes metastasis in mice. J Hum Genet 2009, 54:647-654.

198. Gerke V, Moss SE: Annexins: From Structure to Function. Physiol Rev 2002, 82:331-371

199. Stogbauer F, Weigert J, Neumeier M, Wanninger J, Sporrer D, Weber M, Schaffler A, Enrich C, Wood P, Grewal T, Aslanidis C, Buechler C: Annexin A6 is highly abundant in monocytes of obese and type 2 diabetic individuals and is downregulated by adiponectin in vitro. Exp Mol Med 2009, 41:501-507.

200. Vilá De Muga S, Timpson P, Cubells L, Evans R, Hayes TE, Rentero C, Hegemann A, Reverter M, Leschner J, Pol A, Tebar F, Daly RJ, Enrich C, Grewal T: Annexin A6 inhibits Ras signalling in breast cancer cells. Oncogene 2009, 28:363-377.

201. Sakwe AM, Koumangoye R, Guillory B, Ochieng J: Annexin A6 contributes to the invasiveness of breast carcinoma cells by influencing the organization and localization of functional focal adhesions. Exp Cell Res 2011, 317:823-837.

202. Conroy SE, Latchman DS: Do heat shock proteins have a role in breast cancer? Br J Cancer 1996, 74:717-721.

203. Nirdé P, Derocq D, Maynadier M, Chambon M, Basile I, Gary-Bobo M, Garcia M: Heat shock cognate 70 protein secretion as a new growth arrest signal for cancer cells. Oncogene 2010, 29:117-127.

204. Yokota S, Chiba S, Furuyama H, Fujii N: Cerebrospinal fluids containing anti-HSP70 autoantibodies from multiple sclerosis patients augment HSP70-induced proinflammatory cytokine production in monocytic cells. J Neuroimmunol 2010, 218:129-133.

205. Gan L, Liu D-B, Lu H-F, Long G-X, Mei Q, Hu G-Y, Qiu H, Hu G-Q: Decreased expression of the carboxyl terminus of heat shock cognate 70 interacting protein in human gastric cancer and its clinical significance. Onco Rep 2012, 28:1392-1398.

206. Mizukami S, Kajiwara C, Ishikawa H, Katayama I, Yui K, Udono H: Both CD4+ and CD8+ T cell epitopes fused to heat shock cognate protein 70 (hsc70) can function to eradicate tumors. Cancer Sci 2008, 99:1008-1015.

207. Hu J-Y, Li C-L, Wang Y-W: Altered proteomic pattern in platelets of rats with sepsis. Blood Cells Mol Dis 2012, 48:30-35.

208. Hüttemann M, Helling S, Sanderson TH, Sinkler C, Samavati L, Mahapatra G, Varughese A, Lu G, Liu J, Ramzan R, Vogt S, Grossman LI, Doan JW, Marcus K, Lee I: Regulation of mitochondrial respiration and apoptosis through cell signaling: cytochrome $\mathrm{c}$ oxidase and cytochrome $\mathrm{c}$ in ischemia/ reperfusion injury and inflammation. Biochim Biophys Acta 2012, 1817:598-609.

209. Huang T-C, Chang H-Y, Hsu C-H, Kuo W-H, Chang K-J, Juan H-F: Targeting therapy for breast carcinoma by ATP synthase inhibitor aurovertin B. $J$ Proteome Res 2008, 7:1433-1444.

210. Willers IM, Isidoro A, Ortega AD, Fernández PL, Cuezva JM: Selective inhibition of beta-F1-ATPase mRNA translation in human tumours. Biochem J 2010, 426:319-326.

211. Pan J, Sun L-C, Tao Y-F, Zhou Z, Du X-L, Peng L, Feng X, Wang J, Li Y-P, Liu L, Wu S-Y, Zhang Y-L, Hu S-Y, Zhao W-L, Zhu X-M, Lou G-L, Ni J: ATP synthase ecto-a-subunit: a novel therapeutic target for breast cancer. $J$ Transl Med 2011, 9:211.

212. Chang HJ, Lee MR, Hong S-H, Yoo BC, Shin Y-K, Jeong JY, Lim S-B, Choi HS, Jeong S-Y, Park J-G: Identification of mitochondrial FoF1-ATP synthase involved in liver metastasis of colorectal cancer. Cancer Sci 2007, 98:1184-1191

213. Hermeking H: The 14-3-3 cancer connection. Nat Rev Cancer 2003, 3:931-943.

214. Butt AQ, Ahmed S, Maratha A, Miggin SM: 14-3-3 \{epsilon\} and 14-3-30 inhibit TLR-mediated pro-inflammatory cytokine induction. J Biol Chem 2012. doi:10.1074/jbc.M112.367490.

215. Hodgkinson VC, Agarwal V, ELFadl D, Fox JN, McManus PL, Mahapatra TK, Kneeshaw PJ, Drew PJ, Lind MJ, Cawkwell L: Pilot and feasibility study: comparative proteomic analysis by 2-DE MALDI TOF/TOF MS reveals 143-3 proteins as putative biomarkers of response to neoadjuvant chemotherapy in ER-positive breast cancer. J Proteomics 2012, $75: 2745-2752$
216. Minamida S, Iwamura M, Kodera Y, Kawashima Y, Tabata K, Matsumoto K, Fujita T, Satoh T, Maeda T, Baba S: 14-3-3 protein beta/alpha as a urinary biomarker for renal cell carcinoma: proteomic analysis of cyst fluid. Anal Bioanal Chem 2011, 401:245-252

217. Kim J-M, Noh E-M, Kwon K-B, Kim J-S, You Y-O, Hwang J-K, Hwang B-M, Kim B-S, Lee S-H, Lee SJ, Jung SH, Youn HJ, Lee Y-R: Curcumin suppresses the TPA-induced invasion through inhibition of PKCa-dependent MMPexpression in MCF-7 human breast cancer cells. Phytomedicine 2012, 19:1085-1092

218. Debelec-Butuner B, Alapinar C, Varisli L, Erbaykent-Tepedelen B, Hamid SM Gonen-Korkmaz C, Korkmaz KS: Inflammation-mediated abrogation of androgen signaling: An in vitro model of prostate cell inflammation. Mol Carcinog 2012. doi:10.1002/mc.21948.

219. Zhao Y, Kong X, Li X, Yan S, Yuan C, Hu W, Yang Q: Metadherin mediates lipopolysaccharide-induced migration and invasion of breast cancer cells. PLoS One 2011, 6:e29363.

220. Fatunmbi M, Shelton J, Aronica SM: MMP-9 increases HER2/neu expression and alters apoptosis levels in human mammary epithelial cells (HMEC). Breast Cancer Res Treat 2012, 135:519-530.

221. Chakraborty S, Kaur S, Guha S, Batra SK: The multifaceted roles of neutrophil gelatinase associated lipocalin (NGAL) in inflammation and cancer. Biochim Biophys Acta 2012, 1826:129-169.

222. Pellikainen JM, Ropponen KM, Kataja W, Kellokoski JK, Eskelinen MJ, Kosma V-M: Expression of matrix metalloproteinase (MMP)-2 and MMP-9 in breast cancer with a special reference to activator protein-2, HER2, and prognosis. Clin Cancer Res 2004, 10:7621-7628.

223. Dos Remedios CG, Chhabra D, Kekic M, Dedova IV, Tsubakihara M, Berry DA, Nosworthy NJ: Actin binding proteins: regulation of cytoskeletal microfilaments. Physiol Rev 2003, 83:433-473.

224. Adam L, Vadlamudi R, Mandal M, Chernoff J, Kumar R: Regulation of microfilament reorganization and invasiveness of breast cancer cells by kinase dead p21-activated kinase-1. J Biol Chem 2000, 275:12041-12050.

225. McSherry EA, Brennan K, Hudson L, Hill ADK, Hopkins AM: Breast cancer cell migration is regulated through junctional adhesion molecule-A -mediated activation of Rap1 GTPase. Breast Cancer Res 2011, 13:R31.

226. Huttenlocher A, Horwitz AR: Integrins in cell migration. Cold Spring Harb Perspect Biol 2011, 3:a005074.

227. Friedl $P$, Hegerfeldt $Y$, Tusch $M$ : Collective cell migration in morphogenesis and cancer. Int J Dev Biol 2004, 48:441-449.

228. Bullinger D, Neubauer H, Fehm T, Laufer S, Gleiter CH, Kammerer B: Metabolic signature of breast cancer cell line MCF-7: profiling of modified nucleosides via LC-IT MS coupling. BMC Biochem 2007, 8:25.

229. Buxton ILO, Yokdang N, Matz RM: Purinergic mechanisms in breast cancer support intravasation, extravasation and angiogenesis. Cancer Lett 2010, 291:131-141.

230. Karve TM, Cheema AK: Small changes huge impact: the role of protein posttranslational modifications in cellular homeostasis and disease. $J$ Amino Acids 2011, 2011:207691.

231. Jin H, Zangar RC: Protein modifications as potential biomarkers in breast cancer. Biomark Insights 2009, 4:191-200.

232. Vazquez-Martin A, Oliveras-Ferraros C, Cufí S, Martin-Castillo B, Menendez JA: Metformin and energy metabolism in breast cancer: from insulin physiology to tumour-initiating stem cells. Curr Mol Med 2010, 10:674691.

233. Chen El, Hewel J, Krueger JS, Tiraby C, Weber MR, Kralli A, Becker K, Yates JR III, Felding-Habermann B: Adaptation of energy metabolism in breast cancer brain metastases. Cancer Res 2007, 67:1472-1486.

234. Budczies J, Denkert C, Müller BM, Brockmöller SF, Klauschen F, Györffy B, Dietel M, Richter-Ehrenstein C, Marten U, Salek RM, Griffin JL, Hilvo M, Orešič $M$, Wohlgemuth G, Fiehn O: Remodeling of central metabolism in invasive breast cancer compared to normal breast tissue - a GC-TOFMS based metabolomics study. BMC Genomics 2012, 13:334.

235. Drabovich AP, Pavlou MP, Dimitromanolakis A, Diamandis EP: Quantitative analysis of energy metabolic pathways in MCF-7 breast cancer cells by selected reaction monitoring assay. Mol Cell Proteomics 2012, 11:422-434.

236. Seyfried TN, Shelton LM: Cancer as a metabolic disease. Nutr Metab (Lond) 2010, 7:7.

237. Mira-Y-Lopez R, Zheng WL, Kuppumbatti YS, Rexer B, Jing Y, Ong DE: Retinol conversion to retinoic acid is impaired in breast cancer cell lines relative to normal cells. J Cell Physiol 2000, 185:302-309. 
238. Welsh J: Vitamin D metabolism in mammary gland and breast cancer. Mol Cell Endocrinol 2011, 347:55-60.

239. Verma M, Kagan J, Sidransky D, Srivastava S: Proteomic analysis of cancercell mitochondria. Nat Rev Cancer 2003, 3:789-795.

240. Solazzo M, Fantappiè O, D’Amico M, Sassoli C, Tani A, Cipriani G, Bogani C, Formigli L, Mazzanti R: Mitochondrial expression and functional activity of breast cancer resistance protein in different multiple drug-resistant cell lines. Cancer Res 2009, 69:7235-7242.

241. Chen Y-W, Chou H-C, Lyu P-C, Yin H-S, Huang F-L, Chang W-SW, Fan C-Y, Tu I-F, Lai T-C, Lin S-T, Lu Y-C, Wu C-L, Huang S-H, Chan H-L: Mitochondrial proteomics analysis of tumorigenic and metastatic breast cancer markers. Funct Integr Genomics 2011, 11:225-239.

242. Talhouk R: On cell-matrix interactions in mammary gland development and breast cancer. Cold Spring Harb Perspect Biol 2012, 4:a013540.

243. Manda G, Nechifor MT, Neagu T-M: Reactive Oxygen Species, Cancer and Anti-Cancer Therapies. Curr Chem Biol 2009, 3:342-366.

244. Acharya A, Das I, Chandhok D, Saha T: Redox regulation in cancer: a double-edged sword with therapeutic potential. Oxid Med Cell Longev 2010, 3:23-34

245. Poole LB, Hall A, Nelson KJ: Overview of peroxiredoxins in oxidant defense and redox regulation. Curr Protoc Toxicol 2011, 7:Unit7.9.

246. Sainz RM, Lombo F, Mayo JC: Radical Decisions in Cancer: Redox Control of Cell Growth and Death. Cancers 2012, 4:442-474.

247. Zhang D, Tai LK, Wong LL, Chiu L-L, Sethi SK, Koay ESC: Proteomic study reveals that proteins involved in metabolic and detoxification pathways are highly expressed in HER-2/neu-positive breast cancer. Mol Cell Proteomics 2005, 4:1686-1696.

248. Stresing V, Baltziskueta E, Rubio N, Blanco J, Arriba M, Valls J, Janier M, Clézardin P, Sanz-Pamplona R, Nieva C, Marro M, Dmitri P, Sierra A: Peroxiredoxin 2 specifically regulates the oxidative and metabolic stress response of human metastatic breast cancer cells in lungs. Oncogene 2013, 32:724-735.

249. Feldman DE, Chauhan V, Koong AC: The unfolded protein response: a novel component of the hypoxic stress response in tumors. Mol Cancer Res 2005, 3:597-605.

250. Curtis CD, Thorngren DL, Nardulli AM: Immunohistochemical analysis of oxidative stress and DNA repair proteins in normal mammary and breast cancer tissues. BMC Cancer 2010, 10:9.

251. Dressing GE, Lange CA: Integrated actions of progesterone receptor and cell cycle machinery regulate breast cancer cell proliferation. Steroids 2009, 74:573-576.

252. Roberti A, Macaluso M, Giordano A: Alterations in Cell Cycle Regulatory Genes in Breast Cancer. In Breast Cancer in the Post-Genomic Era. Edited by Giordano A, Normanno N. Totowa, NJ: Humana Press; 2009:55-77.

253. Abraham RT: Cell cycle checkpoint signaling through the ATM and ATR kinases. Genes Dev 2001, 15:2177-2196.

254. Calderwood SK: Heat shock proteins in breast cancer progression-a suitable case for treatment? Int J Hyperthermia 2010, 26:681-685.

255. Nylandsted J, Rohde M, Brand K, Bastholm L, Elling F, Jäättelä M: Selective depletion of heat shock protein 70 ( $\mathrm{Hsp} 70$ ) activates a tumor-specific death program that is independent of caspases and bypasses $\mathrm{BCl}-2$. Proc Natl Acad Sci U S A 2000, 97:7871-7876.

256. Rehman A, Chahal MS, Tang X, Bruce JE, Pommier Y, Daoud SS: Proteomic identification of heat shock protein 90 as a candidate target for p53 mutation reactivation by PRIMA-1 in breast cancer cells. Breast Cancer Res 2005, 7:R765-R774.

257. Caldewood SK, Sherman MY, Ciocca DR (Eds): Heat Shock Proteins in Cancer. Dordrecht: Springer; 2010.

258. Schmitt E, Gehrmann M, Brunet M, Multhoff G, Garrido C: Intracellular and extracellular functions of heat shock proteins: repercussions in cancer therapy. J Leukoc Biol 2007, 81:15-27.

259. Wu J, Shao Z-M, Shen Z-Z, Lu J-S, Han Q-X, Fontana JA, Barsky SH: Significance of Apoptosis and Apoptotic-Related Proteins, BCl-2, and Bax in Primary Breast Cancer. Breast J 2000, 6:44-52.

260. Baekelandt M, Holm R, Nesland JM, Tropé CG, Kristensen GB: Expression of apoptosis-related proteins is an independent determinant of patient prognosis in advanced ovarian cancer. J Clin Oncol 2000, 18:3775-3781

261. Yang M, Yuan F, Li P, Chen Z, Chen A, Li S, Hu C: Interferon regulatory factor 4 binding protein is a novel p53 target gene and suppresses cisplatin-induced apoptosis of breast cancer cells. Mol Cancer 2012, 11:54.
262. Perik PJ, Van der Graaf WTA, De Vries EGE, Boomsma F, Messerschmidt J, Van Veldhuisen DJ, Sleijfer DT, Gietema JA: Circulating apoptotic proteins are increased in long-term disease-free breast cancer survivors. Acta Oncol 2006, 45:175-183.

263. Vejda S, Posovszky C, Zelzer S, Peter B, Bayer E, Gelbmann D, SchulteHermann R, Gerner C: Plasma from cancer patients featuring a characteristic protein composition mediates protection against apoptosis. Mol Cell Proteomics 2002, 1:387-393.

264. Deryugina El, Quigley JP: Matrix metalloproteinases and tumor metastasis. Cancer Metastasis Rev 2006, 25:9-34

265. Mangia A, Malfettone A, Rossi R, Paradiso A, Ranieri G, Simone G, Resta L: Tissue remodelling in breast cancer: human mast cell tryptase as an initiator of myofibroblast differentiation. Histopathology 2011, 58:1096-1106.

266. Parashurama N, Lobo NA, Ito K, Mosley AR, Habte FG, Zabala M, Smith BR, Lam J, Weissman IL, Clarke MF, Gambhir SS: Remodeling of endogenous mammary epithelium by breast cancer stem cells. Stem Cells 2012, 30:2114-2127

267. Kim BG, Gao M-Q, Choi YP, Kang S, Park HR, Kang KS, Cho NH: Invasive breast cancer induces laminin-332 upregulation and integrin $\beta 4$ neoexpression in myofibroblasts to confer an anoikis-resistant phenotype during tissue remodeling. Breast Cancer Res Treat 2012, 14:R88.

268. Timmermans AM, Montazeri H, Trapman-Jansen AM, Martens JW, Foekens JA, Umar A: Abstract 806: Extracellular matrix metalloprotease inducer (EMMPRIN) and CD44 protein complexes are exclusively formed in basaland normal-like breast cancer cell lines. Cancer Res 2012, 72:806-806.

269. Glunde K, Guggino SE, Solaiyappan M, Pathak AP, Ichikawa Y, Bhujwalla ZM: Extracellular acidification alters lysosomal trafficking in human breast cancer cells. Neoplasia 2003, 5:533-545.

270. Imai Y, Ohmori K, Yasuda S, Wada M, Suzuki T, Fukuda K, Ueda Y: Breast cancer resistance protein/ABCG2 is differentially regulated downstream of extracellular signal-regulated kinase. Cancer Sci 2009, 100:1118-1127.

271. Celis JE, Moreira JMA, Cabezón T, Gromov P, Friis E, Rank F, Gromova I: Identification of extracellular and intracellular signaling components of the mammary adipose tissue and its interstitial fluid in high risk breast cancer patients: toward dissecting the molecular circuitry of epithelial-adipocyte stromal cell interactions. Mol Cell Proteomics 2005, 4:492-522.

272. Cos S, González A, Martínez-Campa C, Mediavilla MD, Alonso-González C, Sánchez-Barceló EJ: Estrogen-signaling pathway: a link between breast cancer and melatonin oncostatic actions. Cancer Detect Prev 2006, 30:118-128.

273. Malhotra GK, Zhao X, Band H, Band V: Shared signaling pathways in normal and breast cancer stem cells. J Carcinog 2011, 10:38.

274. Eroles P, Bosch A, Pérez-Fidalgo JA, Lluch A: Molecular biology in breast cancer: intrinsic subtypes and signaling pathways. Cancer Treat Rev 2012, 38:698-707.

275. Thomson CA: Diet and breast cancer: understanding risks and benefits. Nutr Clin Pract 2012, 27:636-650.

276. Giacosa A, Barale R, Bavaresco L, Gatenby P, Gerbi V, Janssens J, Johnston B, Kas K, La Vecchia C, Mainguet P, Morazzoni P, Negri E, Pelucchi C, Pezzotti $\mathrm{M}$, Rondanelli $\mathrm{M}$ : Cancer prevention in Europe: the Mediterranean diet as a protective choice. Eur J Cancer Prev 2013, 22:90-95.

277. Raouf A, Sun Y, Chatterjee S, Basak P: The biology of human breast epithelial progenitors. Semin Cell Dev Biol 2012, 23:606-612.

278. Pallavi R, Giorgio M, Pelicci PG: Insights into the beneficial effect of caloric/ dietary restriction for a healthy and prolonged life. Front Physio/ 2012, 3:318.

279. Cole SW: Chronic inflammation and breast cancer recurrence. J Clin Oncol 2009, 27:3418-3419.

280. Early Breast Cancer Trialists' Collaborative Group (EBCTCG): Effects of chemotherapy and hormonal therapy for early breast cancer on recurrence and 15-year survival: an overview of the randomised trials. Lancet 2005, 365:1687-1717.

281. Slamon DJ, Clark GM, Wong SG, Levin WJ, Ullrich A, McGuire WL: Human breast cancer: correlation of relapse and survival with amplification of the HER-2/neu oncogene. Science 1987, 235:177-182.

282. Ross JS, Slodkowska EA, Symmans WF, Pusztai L, Ravdin PM, Hortobagyi GN: The HER-2 receptor and breast cancer: ten years of targeted anti-HER-2 therapy and personalized medicine. Oncologist 2009, 14:320-368.

283. De Laurentiis M, Arpino G, Massarelli E, Ruggiero A, Carlomagno C, Ciardiello F, Tortora G, D’Agostino D, Caputo F, Cancello G, Montagna E, 
Malorni L, Zinno L, Lauria R, Bianco AR, De Placido S: A meta-analysis on the interaction between HER-2 expression and response to endocrine treatment in advanced breast cancer. Clin Cancer Res 2005, 11:4741-4748.

284. Hayes DF, Thor AD, Dressler LG, Weaver D, Edgerton S, Cowan D, Broadwater G, Goldstein LJ, Martino S, Ingle JN, Henderson IC, Norton L, Winer EP, Hudis CA, Ellis MJ, Berry DA: HER2 and response to paclitaxel in node-positive breast cancer. N Engl J Med 2007, 357:1496-1506.

285. Pritchard KI, Shepherd LE, O'Malley FP, Andrulis IL, Tu D, Bramwell VH, Levine MN: HER2 and responsiveness of breast cancer to adjuvant chemotherapy. N Engl J Med 2006, 354:2103-2111.

286. Gianni L, Pienkowski T, Im Y-H, Roman L, Tseng L-M, Liu M-C, Lluch A, Staroslawska E, de la Haba-Rodriguez J, Im S-A, Pedrini JL, Poirier B, Morandi P, Semiglazov V, Srimuninnimit V, Bianchi G, Szado T, Ratnayake J, Ross G, Valagussa P: Efficacy and safety of neoadjuvant pertuzumab and trastuzumab in women with locally advanced, inflammatory, or early HER2-positive breast cancer (NeoSphere): a randomised multicentre, open-label, phase 2 trial. Lancet Oncol 2012, 13:25-32.

287. Slamon DJ, Leyland-Jones B, Shak S, Fuchs H, Paton V, Bajamonde A Fleming T, Eiermann W, Wolter J, Pegram M, Baselga J, Norton L: Use of chemotherapy plus a monoclonal antibody against HER2 for metastatic breast cancer that overexpresses HER2. N Engl J Med 2001, 344:783-792.

288. Geyer CE, Forster J, Lindquist D, Chan S, Romieu CG, Pienkowski T, JagielloGruszfeld A, Crown J, Chan A, Kaufman B, Skarlos D, Campone M, Davidson N, Berger M, Oliva C, Rubin SD, Stein S, Cameron D: Lapatinib plus capecitabine for HER2-positive advanced breast cancer. N Engl J Med 2006, 355:2733-2743.

289. Urruticoechea A, Smith IE, Dowsett M: Proliferation marker Ki-67 in early breast cancer. J Clin Oncol 2005, 23:7212-7220.

290. Yerushalmi R, Woods R, Ravdin PM, Hayes MM, Gelmon KA: Ki67 in breast cancer: prognostic and predictive potential. Lancet Oncol 2010, 11:174-183.

291. Chang J, Powles TJ, Allred DC, Ashley SE, Makris A, Gregory RK, Osborne CK, Dowsett M: Prediction of clinical outcome from primary tamoxifen by expression of biologic markers in breast cancer patients. Clin Cancer Res 2000, 6:616-621.

292. Fasching PA, Heusinger K, Haeberle L, Niklos M, Hein A, Bayer CM, Rauh C, Schulz-Wendtland R, Bani MR, Schrauder M, Kahmann L, Lux MP, Strehl JD, Hartmann A, Dimmler A, Beckmann MW, Wachter DL: Ki67, chemotherapy response, and prognosis in breast cancer patients receiving neoadjuvant treatment. BMC Cancer 2011, 11:486.

293. Goldhirsch A, Wood WC, Coates AS, Gelber RD, Thürlimann B, Senn H-J: Strategies for subtypes--dealing with the diversity of breast cancer: highlights of the St. Gallen International Expert Consensus on the Primary Therapy of Early Breast Cancer 2011. Ann Oncol 2011, 22:1736-1747.

294. Harbeck N, Dettmar P, Thomssen C, Henselmann B, Kuhn W, Ulm K, Jänicke F, Höfler H, Graeff H, Schmitt M: Prognostic impact of tumor biological factors on survival in node-negative breast cancer. Anticancer Res 1998, 18:2187-2197.

295. Jänicke F, Schmitt M, Pache L, Ulm K, Harbeck N, Höfler H, Graeff H: Urokinase (UPA) and its inhibitor PAl-1 are strong and independent prognostic factors in node-negative breast cancer. Breast Cancer Res Treat 1993, 24:195-208.

296. Annecke K, Schmitt M, Euler U, Zerm M, Paepke D, Paepke S, von Minckwitz G, Thomssen C, Harbeck N: UPA and PAI-1 in breast cancer: review of their clinical utility and current validation in the prospective NNBC-3 trial. Adv Clin Chem 2008, 45:31-45.

297. Jänicke F, Prechtl A, Thomssen C, Harbeck N, Meisner C, Untch M, Sweep CG, Selbmann HK, Graeff H, Schmitt M: Randomized adjuvant chemotherapy trial in high-risk, lymph node-negative breast cancer patients identified by urokinase-type plasminogen activator and plasminogen activator inhibitor type 1. J Natl Cancer Inst 2001, 93:913-920.

298. Adjuvant! Online:; [http://www.adjuvantonline.com/index.jsp]

299. Mook S, Schmidt MK, Rutgers EJ, van de Velde AO, Visser O, Rutgers SM, Armstrong N, Van't Veer L, Ravdin PM: Calibration and discriminatory accuracy of prognosis calculation for breast cancer with the online Adjuvant! program: a hospital-based retrospective cohort study. Lancet Oncol 2009, 10:1070-1076.

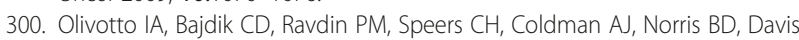
GJ, Chia SK, Gelmon KA: Population-based validation of the prognostic model ADJUVANT! for early breast cancer. J Clin Oncol 2005, 23:2716-2725.

301. Ozanne EM, Braithwaite D, Sepucha K, Moore D, Esserman L, Belkora J: Sensitivity to input variability of the Adjuvant! Online breast cancer prognostic model. J Clin Oncol 2009, 27:214-219.

302. Eastern Cancer Registry and Information Centre: PREDICT:; [http://www. predict.nhs.uk/]

303. Wishart GC, Bajdik CD, Azzato EM, Dicks E, Greenberg DC, Rashbass J, Caldas C, Pharoah PDP: A population-based validation of the prognostic model PREDICT for early breast cancer. Eur J Surg Oncol 2011, 37:411-417.

304. Wishart GC, Bajdik CD, Dicks E, Provenzano E, Schmidt MK, Sherman M, Greenberg DC, Green AR, Gelmon KA, Kosma V-M, Olson JE, Beckmann MW, Winqvist R, Cross SS, Severi G, Huntsman D, Pylkäs K, Ellis I, Nielsen TO, Giles G, Blomqvist C, Fasching PA, Couch FJ, Rakha E, Foulkes WD, Blows FM, Bégin LR, Van't Veer LJ, Southey M, Nevanlinna H, Mannermaa A, Cox A, Cheang M, Baglietto L, Caldas C, Garcia-Closas M, Pharoah PDP: PREDICT Plus: development and validation of a prognostic model for early breast cancer that includes HER2. Br J Cancer 2012, 107:800-807.

305. Cheang MCU, van de Rijn M, Nielsen TO: Gene expression profiling of breast cancer. Annu Rev Pathol 2008, 3:67-97.

306. Perou CM, Sørlie T, Eisen MB, van de Rijn M, Jeffrey SS, Rees CA, Pollack JR, Ross DT, Johnsen H, Akslen LA, Fluge O, Pergamenschikov A, Williams C, Zhu SX, Lønning PE, Børresen-Dale AL, Brown PO, Botstein D: Molecular portraits of human breast tumours. Nature 2000, 406:747-752.

307. Rouzier R, Perou CM, Symmans WF, Ibrahim N, Cristofanilli M, Anderson K, Hess KR, Stec J, Ayers M, Wagner P, Morandi P, Fan C, Rabiul I, Ross JS, Hortobagyi GN, Pusztai L: Breast cancer molecular subtypes respond differently to preoperative chemotherapy. Clin Cancer Res 2005, 11:56785685 .

308. Smid M, Wang Y, Zhang Y, Sieuwerts AM, Yu J, Klijn JGM, Foekens JA, Martens JWM: Subtypes of breast cancer show preferential site of relapse. Cancer Res 2008, 68:3108-3114.

309. Sørlie T, Perou CM, Tibshirani R, Aas T, Geisler S, Johnsen H, Hastie T, Eisen MB, van de Rijn M, Jeffrey SS, Thorsen T, Quist H, Matese JC, Brown PO, Botstein D, Lønning PE, Børresen-Dale AL: Gene expression patterns of breast carcinomas distinguish tumor subclasses with clinical implications. Proc Natl Acad Sci U S A 2001, 98:10869-10874.

310. Paik S, Shak S, Tang G, Kim C, Baker J, Cronin M, Baehner FL, Walker MG, Watson D, Park T, Hiller W, Fisher ER, Wickerham DL, Bryant J, Wolmark N: A multigene assay to predict recurrence of tamoxifen-treated, nodenegative breast cancer. N Engl J Med 2004, 351:2817-2826.

311. Veer LJV't, Dai H, van de Vijver MJ, He YD, Hart AAM, Mao M, Peterse HL, van der Kooy K, Marton MJ, Witteveen AT, Schreiber GJ, Kerkhoven RM, Roberts C, Linsley PS, Bernards R, Friend SH: Gene expression profiling predicts clinical outcome of breast cancer. Nature 2002, 415:530-536.

312. Buyse M, Loi S, Van't Veer L, Viale G, Delorenzi M, Glas AM, D' Assignies MS, Bergh J, Lidereau R, Ellis P, Harris A, Bogaerts J, Therasse P, Floore A, Amakrane M, Piette F, Rutgers E, Sotiriou C, Cardoso F, Piccart MJ: Validation and clinical utility of a 70-gene prognostic signature for women with node-negative breast cancer. J Natl Cancer Inst 2006, 98:1183-1192.

313. van de Vijver MJ, He YD, Veer LJ V, Dai H, Hart AAM, Voskuil DW, Schreiber GJ, Peterse JL, Roberts C, Marton MJ, Parrish M, Atsma D, Witteveen A, Glas A, Delahaye L, van der Velde T, Bartelink H, Rodenhuis S, Rutgers ET, Friend $\mathrm{SH}$, Bernards R: A gene-expression signature as a predictor of survival in breast cancer. N Engl J Med 2002, 347:1999-2009.

314. Straver ME, Glas AM, Hannemann J, Wesseling J, van de Vijver MJ, Rutgers EJT, Vrancken Peeters M-JTFD, van Tinteren H, Van't Veer LJ, Rodenhuis S: The 70-gene signature as a response predictor for neoadjuvant chemotherapy in breast cancer. Breast Cancer Res Treat 2010, 119:551-558.

315. Paik S, Tang G, Shak S, Kim C, Baker J, Kim W, Cronin M, Baehner FL, Watson D, Bryant J, Costantino JP, Geyer CE Jr, Wickerham DL, Wolmark N: Gene expression and benefit of chemotherapy in women with node-negative, estrogen receptor-positive breast cancer. J Clin Oncol 2006, 24:3726-3734.

316. Albain KS, Barlow WE, Shak S, Hortobagyi GN, Livingston RB, Yeh I-T, Ravdin P, Bugarini R, Baehner FL, Davidson NE, Sledge GW, Winer EP, Hudis C, Ingle JN, Perez EA, Pritchard Kl, Shepherd L, Gralow JR, Yoshizawa C, Allred DC, Osborne CK, Hayes DF: Prognostic and predictive value of the 21-gene recurrence score assay in postmenopausal women with node-positive, oestrogen-receptor-positive breast cancer on chemotherapy: a retrospective analysis of a randomised trial. Lancet Oncol 2010, 11:55-65. 
317. Rutgers E, Piccart-Gebhart MJ, Bogaerts J, Delaloge S, Veer LVT, Rubio IT, Viale G, Thompson AM, Passalacqua R, Nitz U, Vindevoghel A, Pierga J-Y, Ravdin PM, Werutsky G, Cardoso F: The EORTC 10041/BIG 03-04 MINDACT trial is feasible: results of the pilot phase. Eur J Cancer 2011, 47:2742-2749.

318. Sparano JA, Paik S: Development of the 21-gene assay and its application in clinical practice and clinical trials. J Clin Oncol 2008, 26:721-728.

doi:10.1186/1878-5085-4-6

Cite this article as: Golubnitschaja et al:: Risk assessment, disease prevention and personalised treatments in breast cancer: is clinically qualified integrative approach in the horizon?. The EPMA Journal 2013 4:6.

\section{Submit your next manuscript to BioMed Central and take full advantage of:}

- Convenient online submission

- Thorough peer review

- No space constraints or color figure charges

- Immediate publication on acceptance

- Inclusion in PubMed, CAS, Scopus and Google Scholar

- Research which is freely available for redistribution 